\title{
A Model for Public-Private Partnership in the Public Services Sector
}

\begin{abstract}
Amirhassan Zarei-Rahro ${ }^{1}$ Ph.D. Student, Department of Public Administration, Faculty of Management of Economics, Islamic Azad University, Science and Research Branch, Tehran, Iran.
\end{abstract}

Habibollah Taherpour Kalantari ${ }^{2}$ Assistant Professor, Department of Management, Institute for Management and Planning Studies, Tehran, Iran (Corresponding Author).

Reza Najaf-Beigi ${ }^{3}$ Professor, Public Administration, Science and Research Branch, Islamic Azad University, Tehran, Iran.

\begin{abstract}
Public-private partnership is a new way to expand public services through the private sector, which should be increasingly taken into consideration in Iran. This research aims at identifying effective factors in the success of public-private partnership and providing a model for the public services sector in Iran. The data collection tool was a questionnaire and the analytical unit and the statistical population of the study were all public-private partnership projects in Tehran. The collected data were analyzed using exploratory factor analysis and multivariate regression. Results show that five categories of factors affect the success of a public-private partnership, which include: optimal management, trust building, information and knowledge use, attention to the interests of the people and financing. Based on the findings, the optimal management factor has the greatest impact and financing factor has the least impact on the success of the public-private partnership. Also, the rate of success for the public-private partnership is lower than the theoretical average. According to the findings, in order for public-private partnership to succeed in Iran, it is necessary to pay special attention to these five key factors.
\end{abstract}

Keywords: Public-private Partnership Model, Public Services, Trust Building, Optimal Management, Attention to the Interests of the People.

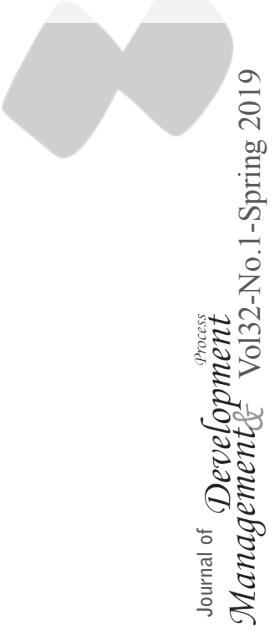

1. zarei1395@gmail.com

2. habtaherk@yahoo.com

3. rezanajafbagy@yahoo. com 

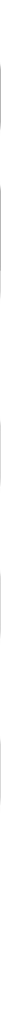

1. دانشجوى دكترى گروه مديريت

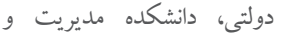
اقتصاد، دانشگًاه آزاد اسلامى، واحد علوم تحقيقات تهران،

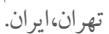
zarei1395@gmail.com r. استاديار گرروه مديريت دولتى، موسسه عالى آموزش و بيزوهش مدي دونى مديريت و برنامهريزى، تهران، آموزئ برونان اير ان (نويسنده مسئول). habtaherk@yahoo.com r. استاد مديريت دولتى، دانشكده مديريت و اقتصاد، دانشگاه آزاد

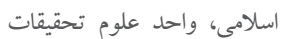
تهر ان، تهر ان، ايران. rezanajafbagy@yahoo.com شراكت عمومى ـ خصوصى، روشى نو براى گَسترش و ارتقاى خدمات دولتى با همكارى إنى

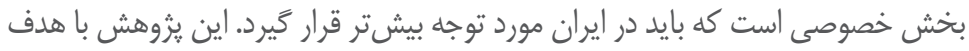

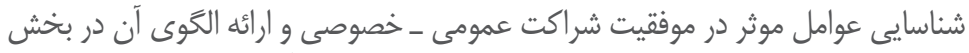

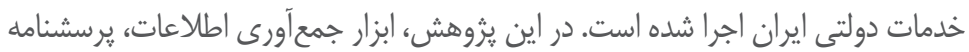

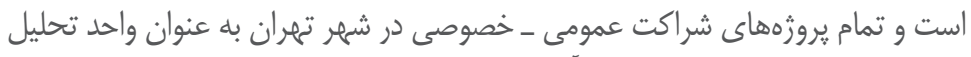

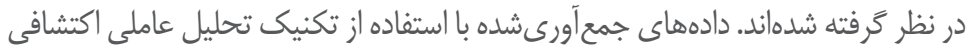

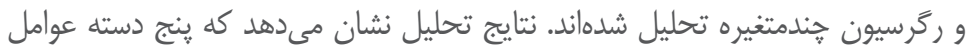

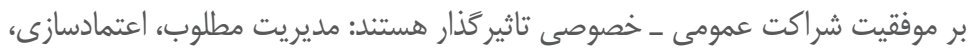

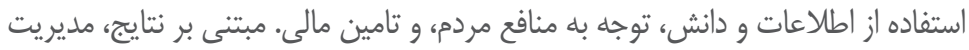

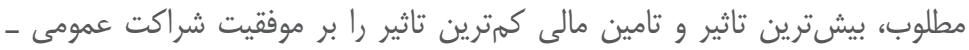

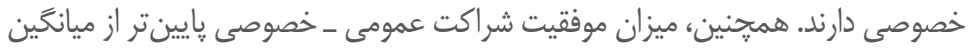

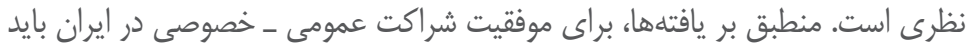
به اين ينج عامل كليدى توجه ويزه داشت.

كليلوازهها: الكوى شر اكت عمومى ـ خصوصى، خدمات عمو مى، اعتمادسازى، ملديريت مطلوبـ، توجه بـ به منافع مردم. 


\section{مقام}

در ايران، نياز به حضور بخش خصوصى به دليل تحريمهاى بينالمللى، كمبود بودجههاى عمرانى دولت و سرمايه كذارى خارجى، افزايش رو به رشد درخواست خدمات عمومى ناشى از رشد

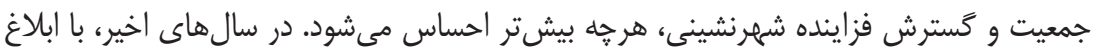

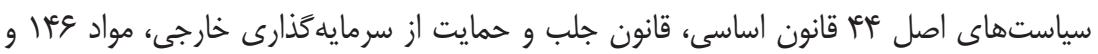

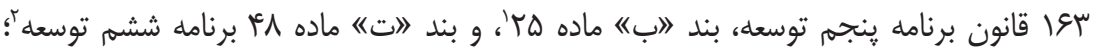
يعنى استفاده از مشاركت بخش خصوصى در قالب روشهايى مانند مشاركت يا واگذارى امتياز و طراحى، تدارى و تامين ساخت، بهرهبردارى، و انتقال، زمينه افزايش مشاركت بخش خصوصى مصوصى در سرمايهگذارى در ايران فراهم شده است. ولى هنوز، استفاده از ظرفيتهاى بالاى مدلهاى شراكت عمومى-خصوصى با محدوديتها و موانع زيادى روبلرو است كه بايد شناسايى شوند و برناملريزى لازم براى رفع آنها صورت گيرند. يكى از مسائل مهم دنيا در مورد توسعه، ايجاد زيرساخت و بهبود ارائه خدمات عمومى است. ولى امروزه روشن است كه بخش دولتى، بده بدون كمى بخش خصوصى نمىتواند زيرساختها و خدمات عمومى را بهطور بهينه و مناسب ايجاد كند. برخى مسائل موجود در كشور كه ضرورت توسعه شراكت عمومى ـ خصوصى را در ايران ايجاد نمودهاند عبارتاند از: ا. بزرى شدن بدنه دولت و سهم بالاى اعتبارهاى هزينهاى؛ ז. وجود

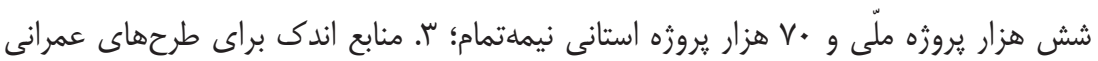

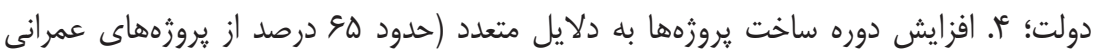
دولت در موعد زمانى تعيينشده تمام نشدهاند و دوره ساخت آنها به rا إل سال افزايش يافته است)؛

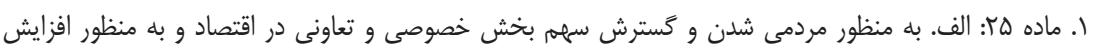

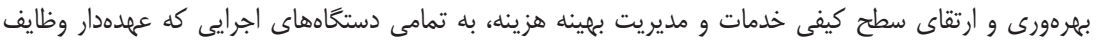

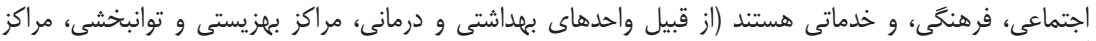

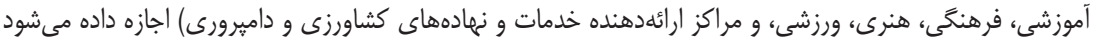

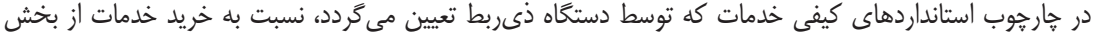

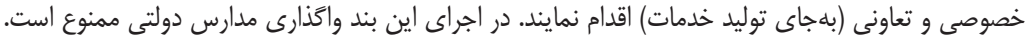

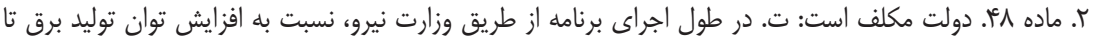

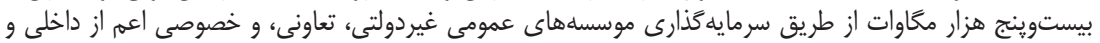

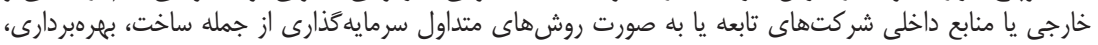

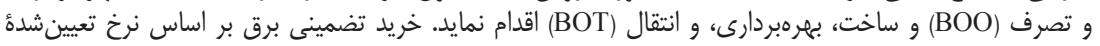


ه. ناكارامدى فرايندهاى بيدايش، اجرا، بهرهبردارى و مهمتر از همه، ضعف ساختارى بايش و نظارت بر طرحهاى عمرانى؛ و بازماندن دولت در رسيدگى به وظايف حاكميتى به دليل مشغله

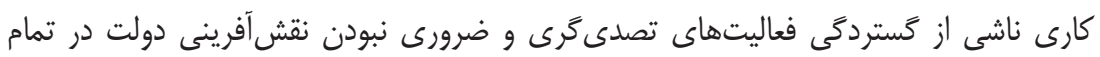

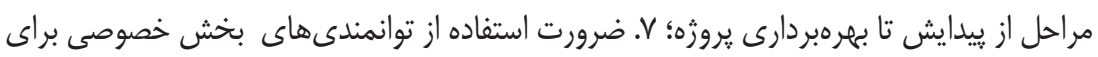

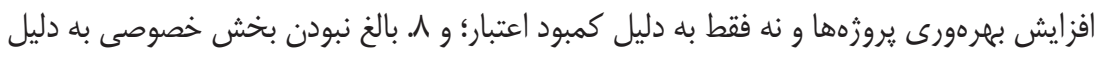
جايخاه رقابتى دولت بهجاى نقش حمايتى آن.

جدول ا: يروزههاى دولتى نيمهتمام ملّى و استانى به تفكيك نوع بروزه در سال هوسا

\begin{tabular}{|c|c|c|}
\hline \multicolumn{2}{|c|}{ تعداد يروزه } & \multirow{2}{*}{ نوع بروزه } \\
\hline استانى & ملى & \\
\hline rVart & rqYq & احداث \\
\hline$v \cdots r$ & $1 \cdot 9$ & تجهيز \\
\hline $10 r a \mid$ & VYY & تعمير، مرمت، بازسازى \\
\hline Nץ & rq & تعهدها \\
\hline$\Delta r)^{r}$ & $9 V T$ & توسعه \\
\hline мᄉґ & TYA & خدمات \\
\hline- & ro & طر احى تفصيلى \\
\hline DQT & 199 & مطالعه بنيادى \\
\hline IVT. & $r \Delta \wedge$ & مطالعه طراحى \\
\hline- & TY & نظارت \\
\hline- & 190 & 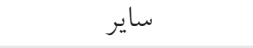 \\
\hline \multirow[t]{2}{*}{$V .910$} & $9 \cdot 49$ & جمع \\
\hline & V9994 & جمع كل \\
\hline
\end{tabular}

يس، يُوهش حاضر به دنبال اين است كه با شناسايى تمامى عوامل موثر و ميزان اهميت

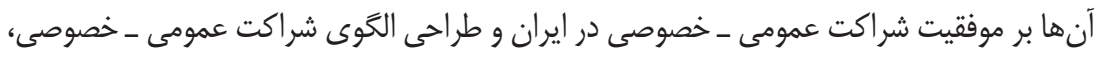

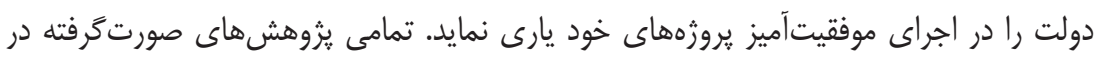

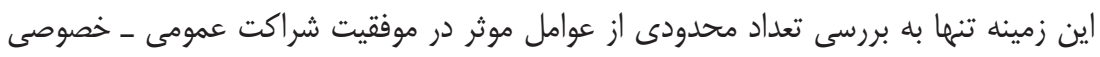

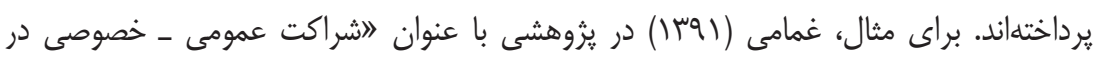


توسعه زيرساختها در ايران بر اساس مبانى مذكور در قانون اساسى و قوانين عادى" عدم حمايت

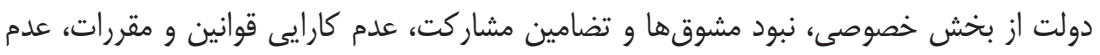

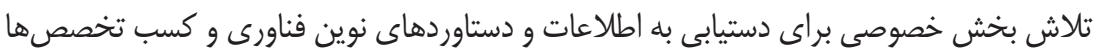

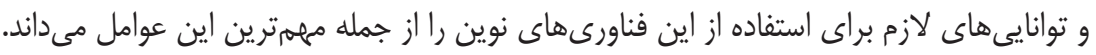

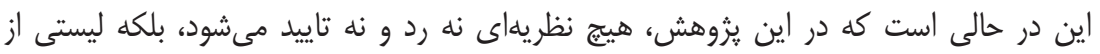

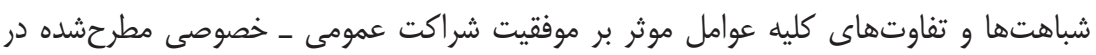

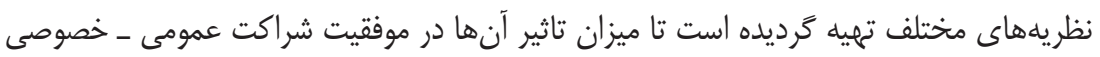

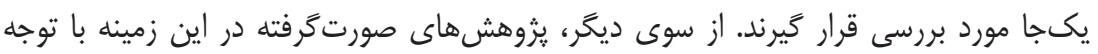

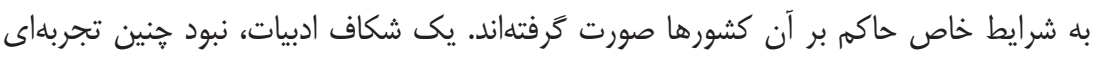

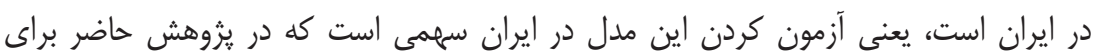

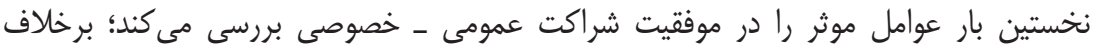

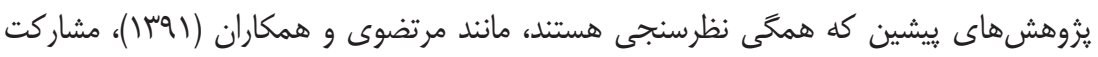

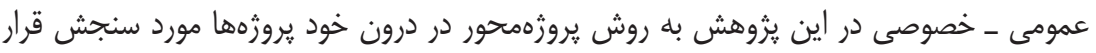

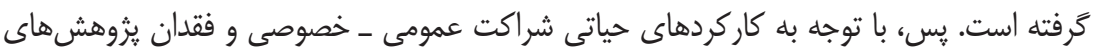

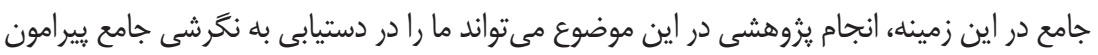
شراكت عمومى ـ خصوصى و برخوردارى از مزاياى آن يارى رساند.

\section{مبانى نظرى و ويشينهُ يزووهش}

شراكت عمومى ـ خصوصى عبارت است از اترتيباتى كه هر دو بخش عمومى و خصوصى، براى

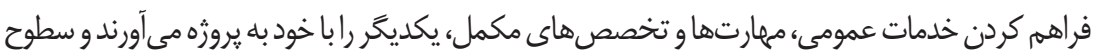
مختلفى را از اشتغال در يروزه از خود به نمايش مى كذارنده (Sudarto et al., 2007: 251). در تعريف

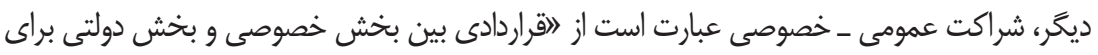

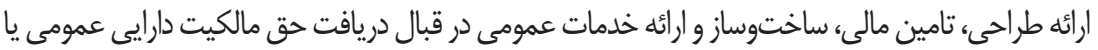
دريافت يول از مصرفكنندكانه (Bloomfield, 2006: 403). شراكت عمومى ـ خصوصى براى شركا،

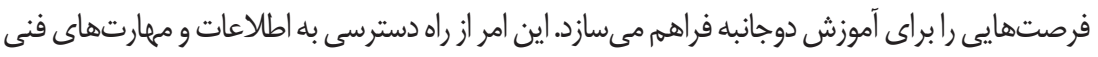
و شايستخى هايى كه هر يك از طرفها مشاركت دارند، فراهم مى گردد (Kettler \& Towse, 2002).

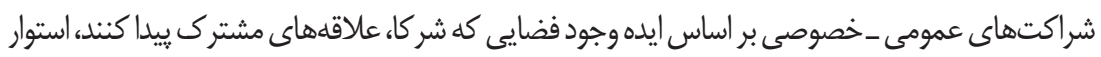
هستند. دليل اصلى هر نوع همكارى، تهديل، علايق شخصى، واهداف مشتر كاست (McQuaid, 2000). 
مبانى نظرى شراكت عمومى ـ خصوصى ريشه در جنبش مديريت دولتى نوين دارد. از آنجايى

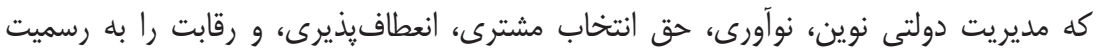

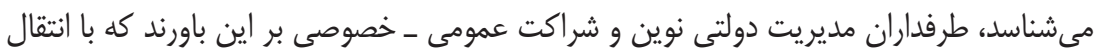
مسئوليت ارائه خدمات به بخش خصوصى، بخش دولتى به قدرت مهار محركهاى مبتى مبنى بر بازار برمى تقويت مشاركت داوطلبانه بخش خصوصى مىشود تا ارائه كالاهاى عمومى و ايجاد شراكتهاى عمومى ـ خصوصى به عنوان ابزار مديريت نوين بهبود يابند (Khanom, 2010).

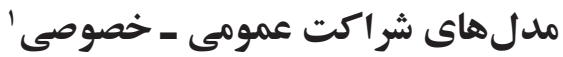

بر اساس انواع مختلف قرارداد و انتقال ريسك، دامنهاى از الخوهاى شراكت عمومى ـ خصوصى وجود دارد كه در اين الكوها مسئوليتها و ريسكها بين شركاى عمومى و خصوصى از راههاى مختلف تخصيص مى يابد. اين راهها عبارتاند از: طراحى ـ ساخت (DB)'؛؛ خريد ـ ساخت ـ راهاندازى

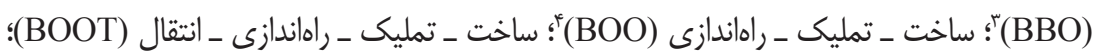
ساخت _ راهاندازى ـ انتقال (BOT)؛؛ ساخت ـاجاره _ راهاندازى ـ انتقال (BLOT)؛ طراحى ـ ساخت ـ تامين مالى ـ راهاندازى (DBFO)؛ يروانه (اجازه) راهاندازى (Yang et al., 2017). در اين يثوهش، به سه يرسش پاسخ داده مىشود: ا. عوامل موثر بر موفقيت شراكت عمومى ـ خصوصى كداماند؟ به اين منظور، فهرستى از متغيرهاى استخراجشده مبتنى بر يزوهشهاى ييشين تهيه شده است، و به كمى يرسشنامه عوامل موثر در يروزههاى شراكت عمومى ـ خصوصى ايران شناسايى شدهاند؛ r. ميزان تاثير هر يك از عوامل جقدر

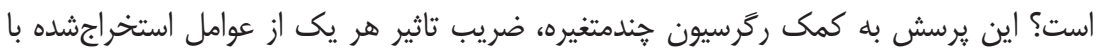
يرسشنامه تعيين شده است؛ و ّ. موفقيت يروزههاى شراكت عمومى ـ خصوصى جه ميزان است؟ اين يرسش نيز به كمى آزمون T تكىمتغيره پاسخ داده مى إسود.

1. Public Private Partnerships Models

2. Design-Build (DB)

3. Buy-Build-Operate (BBO)

4. Build-Own-Operate (BOO)

5. Build-Operate-Transfer

6. Build-Lease-Operate-Transfer

7. Design-Build-Finance-Operate

8. Finance Only

9. Operate \& Maintenance Contract 
با توجه به يُوهشهاى فراوان درباره عوامل موثر بر موفقيت شراكت عمومى ـ خصوصى در

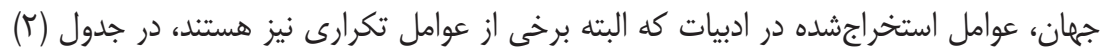

آورده مىشود.

جدول ب: متغيرهاى موثر بر موفقيت شراكت عمومى ـ خصوصى

\begin{tabular}{|c|c|}
\hline 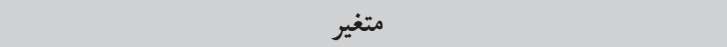 & 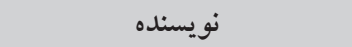 \\
\hline 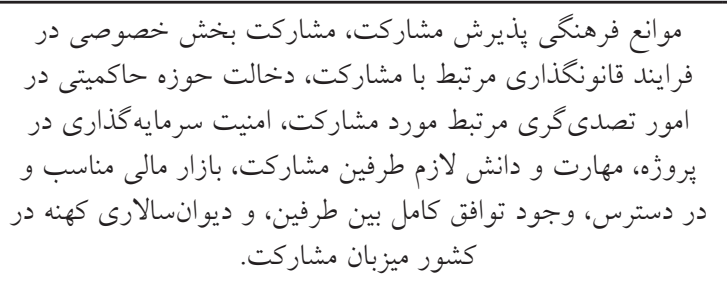 & 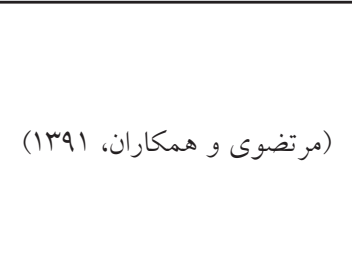 \\
\hline كنترل قضايى دولت & ( El- Gohary et al., 2006) \\
\hline 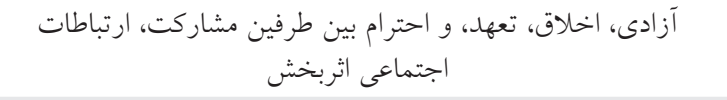 & (Trafford \& Proctor, 2006) \\
\hline 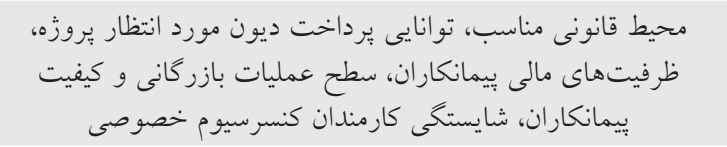 & (Zhao et al., 2013) \\
\hline 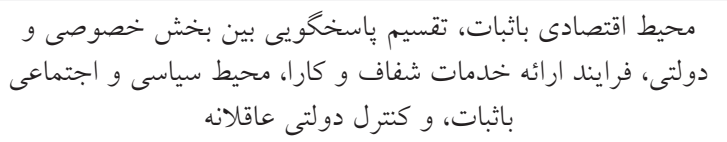 & (ke et al., 2010) \\
\hline 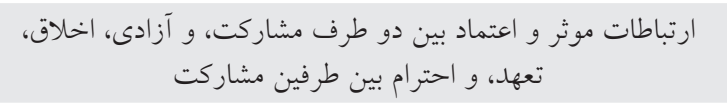 & (Jamali, 2004) \\
\hline 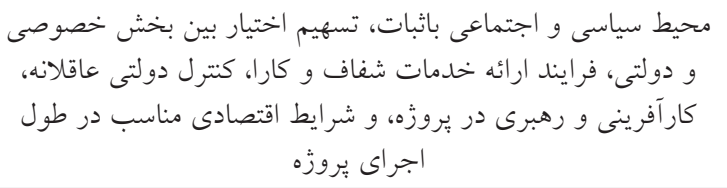 & (Chan et al., 2009) \\
\hline 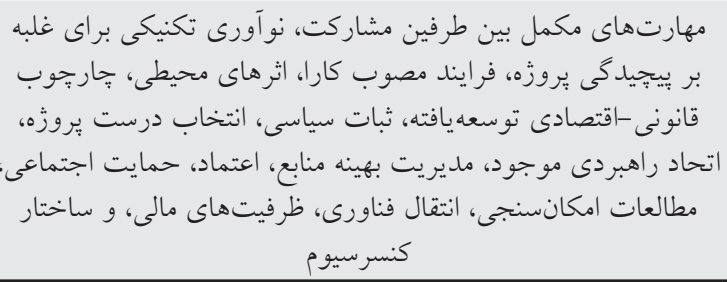 & (Tang, 2011) \\
\hline
\end{tabular}




نويسنده

دخالت دولت با ارائه يشتيبانى براى يروزه، قدرت تقسيمشده بين بخش خصوصى و دولتى نئن

(Stonehouse et al., 1996)

$$
\text { كنسرسيوم قوى بخش خصوصى، قدرت تقسيمشده بين بخش }
$$

$$
\text { كنترل قضايى دولت، حكمرانى خوب در كشور ميزبان }
$$

(Alinaitwe \& Ayesiga, 2013)

$$
\text { توجيه اقتصادى يروزة }
$$

(Abdul-Rashid et al., 2006)

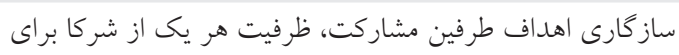

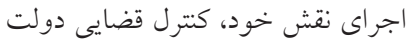

(Rondinelli, 2004)

مهارت و دانش لازم طرفين مشاركت، بازار مالى مناسب و در

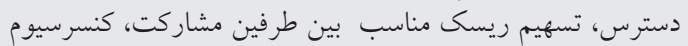

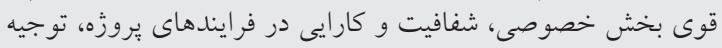

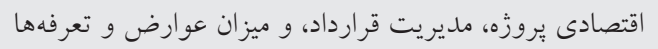

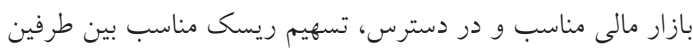

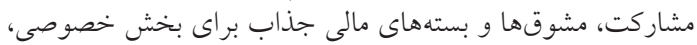

(Kwak et al., 2009)

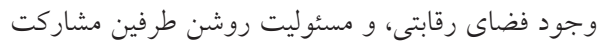

بازار مالى مناسب و در دسترس، تسهيم ريسك مناسب بين طرفين

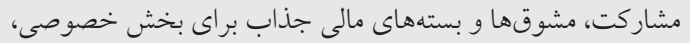

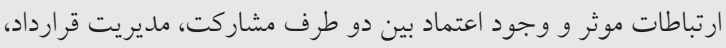

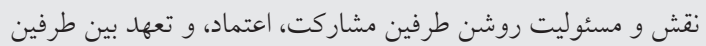

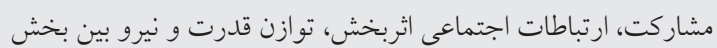

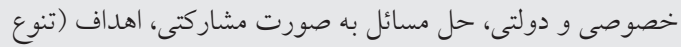

(Kalampukatt \& Mittal,

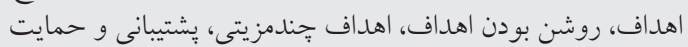

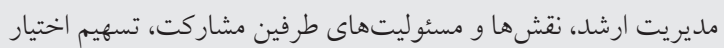

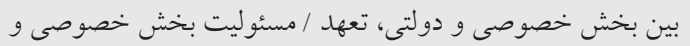

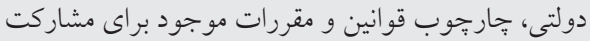

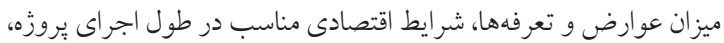

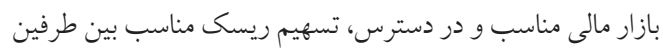

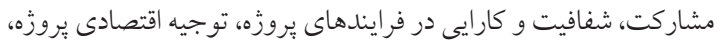
(Qiao et al., 2001)

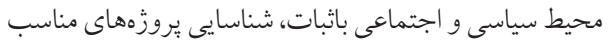
بازار مالى مناسب و در دسترس، محيط سياسى و اجتماعى باتبات، ونيط وجود فضاى رقابتى (فرايند تدارى رقابتى و انتخاب رقابتى دابتى كنسرسيوم

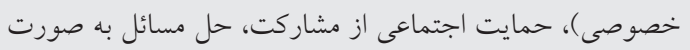

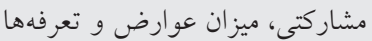


ادامه جدول r: متغيرهاى موثر بر موفقيت شراكت عمومى ـ خصوصى

\begin{tabular}{|c|c|}
\hline 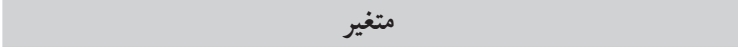 & نويسنده \\
\hline بخش دولتى قوى، فرايند تهيه و تدارى بروزه، بازار مالى جذاب، & (Haarhoff, 2009) \\
\hline 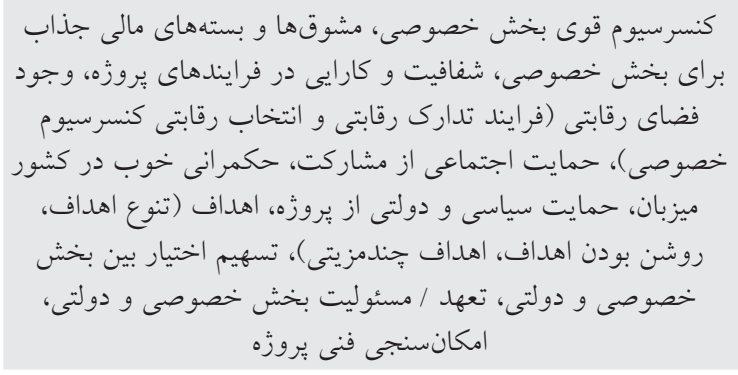 & (Hardcastle et al., 2005) \\
\hline 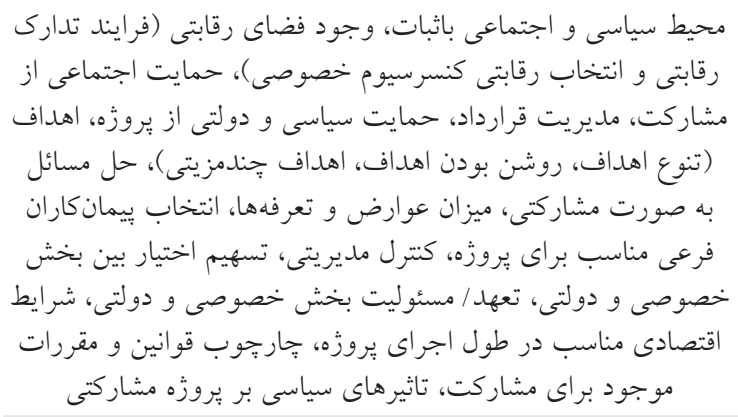 & (Wah, 2006) \\
\hline 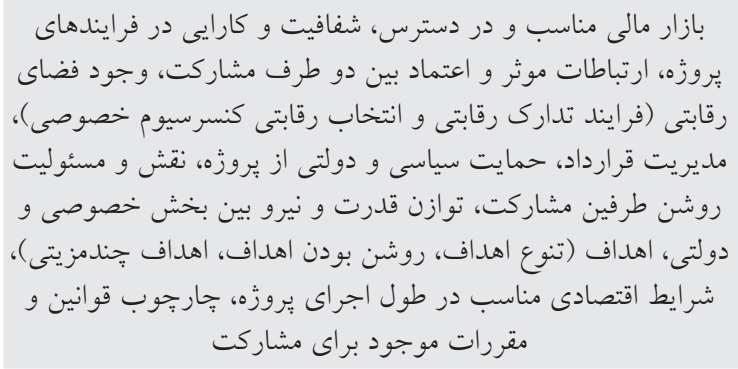 & (Cheung et al., 2009) \\
\hline 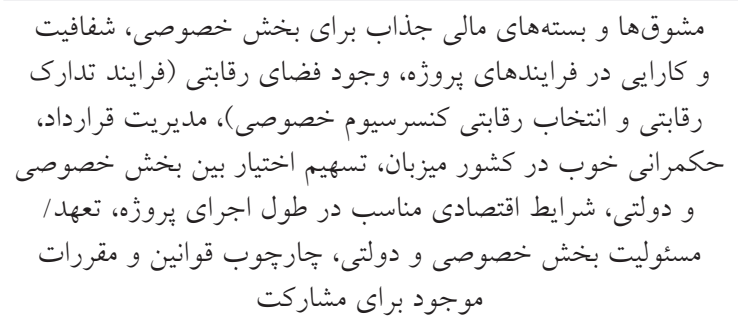 & (Helmy, 2011) \\
\hline
\end{tabular}




\begin{tabular}{|c|c|}
\hline 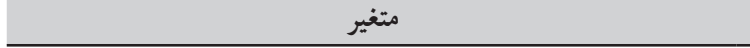 & ن يسنده \\
\hline 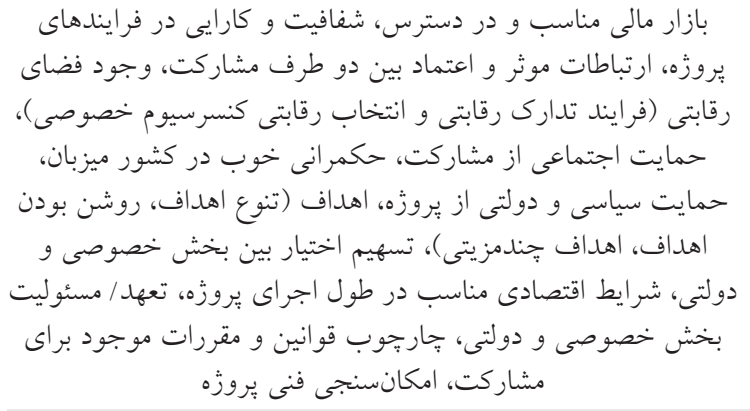 & (Ismail, 2013) \\
\hline 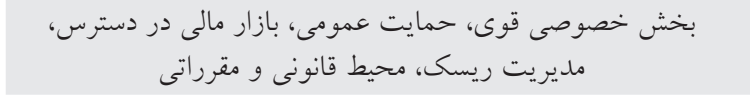 & (Chan et al., 2008) \\
\hline 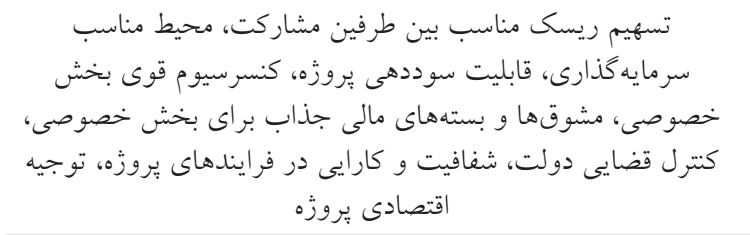 & (Zhang, 2005) \\
\hline 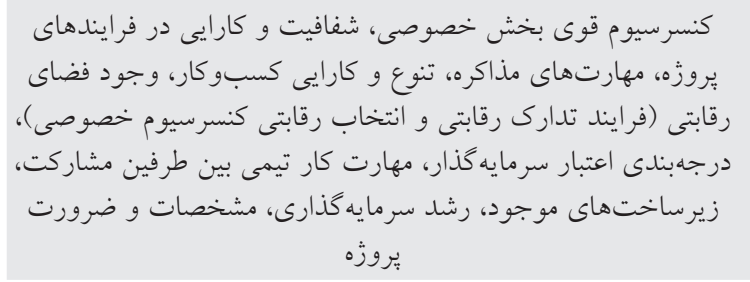 & (Jefferies, 2006) \\
\hline 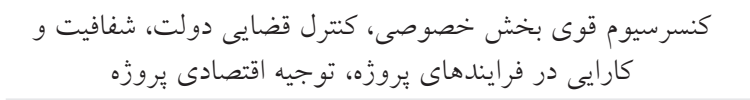 & (Corbett \& Smith, 2006) \\
\hline فرايند زمانبر و ييّجيده مذاكره، سختى تعيين كيفيت خدمات، تضاد & (Akintoye et al., 2003) \\
\hline مهارت و دانش لازم طرفين مشاركت، حمايت سياسى و دولتى از & (Dulaimi et al., 2010) \\
\hline 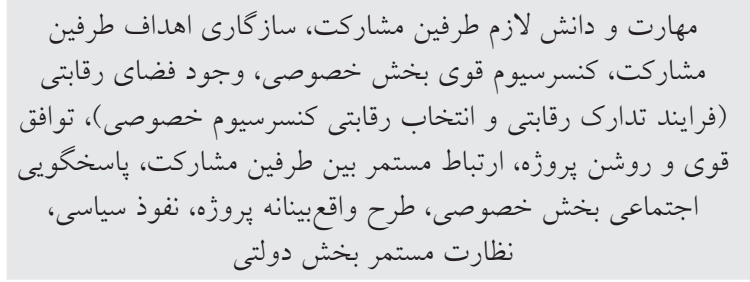 & $($ Aziz, 2010) \\
\hline
\end{tabular}


ادامه جدول r: متغيرهاى موثر بر موفقيت شراكت عمومى - خصوصى

\begin{tabular}{|c|c|}
\hline متغير & نويسنده \\
\hline 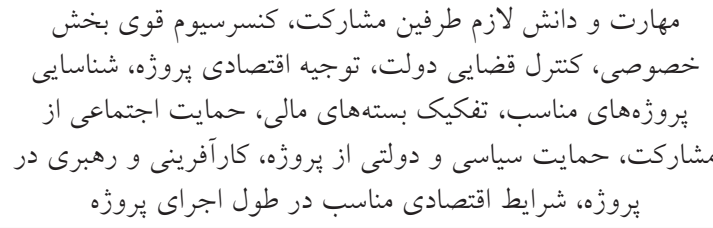 & (Tiong, 1996) \\
\hline طهارت و دانش لازم طرفين مشاركت، تسهيم ريسك فرايند مناسب بين & (liu \& Wilkinson, 2011) \\
\hline 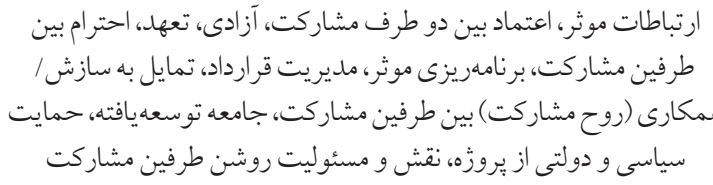 & (Jacobson \& Ok Choi, 2008) \\
\hline مهارت و دانش لازم طرفين مشاركت، تسهيم ريسك مناسب، فرائد بين & (Grimsey \& lewis, 2007) \\
\hline
\end{tabular}

با توجه به جدول (r) و بررسى مقالهها و كتب مربوط به موضوع يثوهش، مشخص شد گروهى از يثوهشخران برخى متغيرها را به صورت كلى و برخى به صورت جزئى مطرح نمودهاند. همجنين، برخى متغيرهاى ارائهشده از سوى يزوهشگران با متغيرهاى ارائهشده از سوى ديگر يزوهشگران

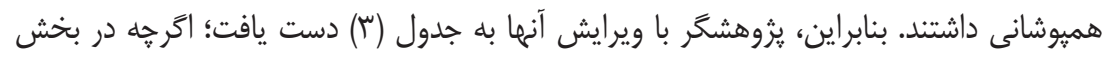
يرسشنامه نهايیى تمامى متغيرها را مورد سنجش قرار داده است.

جدول "ج: جدول مولفهها و شاخصهاى يخوهش

\begin{tabular}{|c|c|}
\hline شاخص & 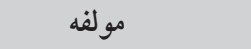 \\
\hline l. رقابت باز r. رقابت عادلانه & رقابت \\
\hline 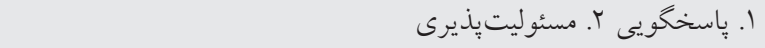 & باسخخويى \\
\hline 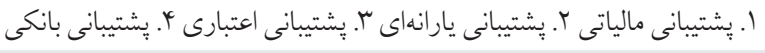 & بشتشبيانى مالى \\
\hline ا. توانايى مديريتى ؟. توانايى فنى & شايستخى و مهارت \\
\hline ا. تعهد عملى ؟. تعهد نظرى & تعهجد \\
\hline ا. مطلوبيت قانونى ז. شفافيت قانونى ؟. انطباق قانونى ب. انعطاف قانونى & جارجوب قانونى \\
\hline 1. حمايت دولتى ؟. حمايت سياسى & حمايت و ثبات سياسى \\
\hline ا. امكانسنجى محيطزيستى ؟. امكانسنجى اجتماعى و فرهنكى & توجه به توسعه يايدار \\
\hline
\end{tabular}


ادامه جدول با: جدول مولفهها و شاخصهاى يخوهش

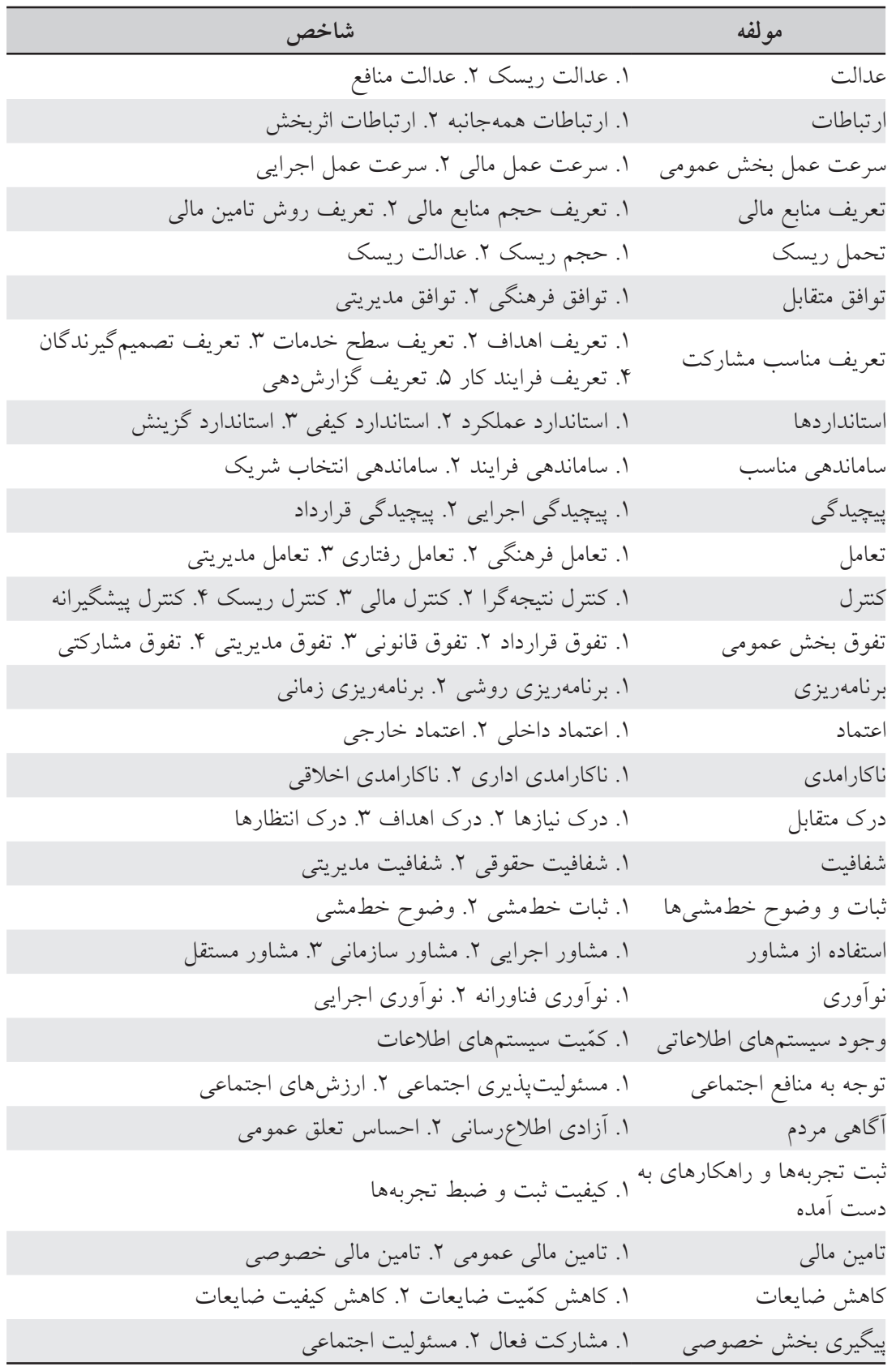




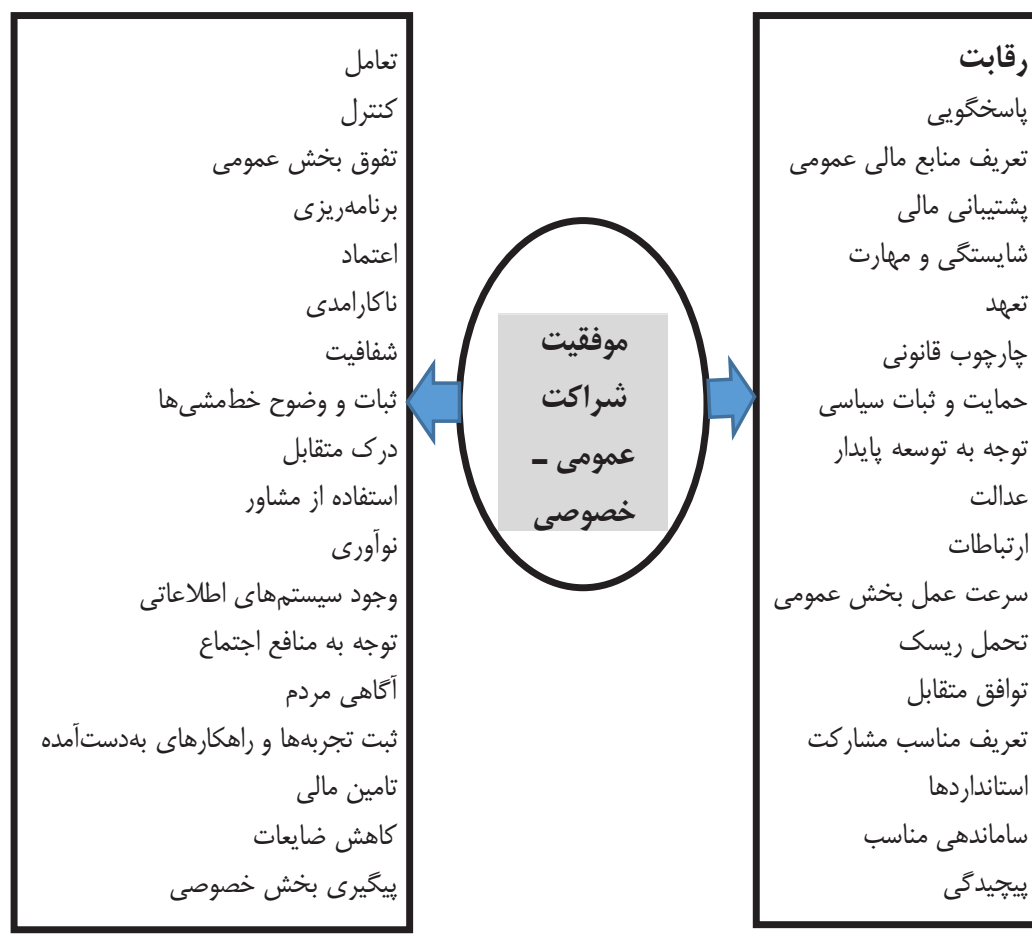

شكل 1: مدل مفهومى ثزوهش

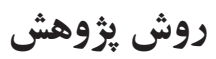

واحد تحليل و جامعه آمارى اين يثوهش، يروزههاى شراكت عمومى ـ خصوصى در وزارت راه

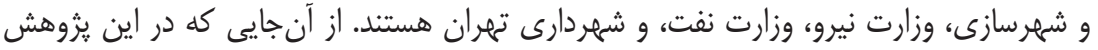

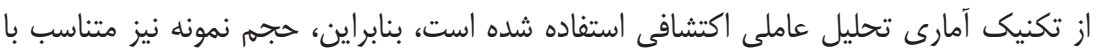
اين تكنيك انتخاب گرديده است. با توجه به محدوديت يروزههاى شراكت عمومى ـ خصوصى . تهى تعداد .ا يروزه به عنوان حجم نمونه از سازمانهايى كه مايل به همكارى بودند، شناسايى شد و

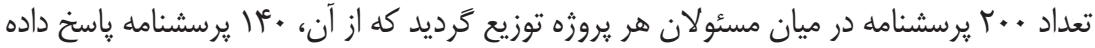

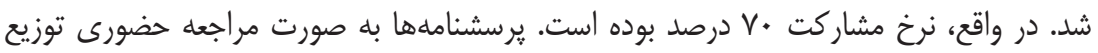
شدند و جمعآورى يرسشنامهها در طول سه ماه انجام گرديد. روش نمونهگيرى نيز، در دسترس مس بوده است. در اين يخوهش، با مطالعه يُوهشها، منابع يُوهشى و نظر خبر گان به تهيه يرسشنامه 


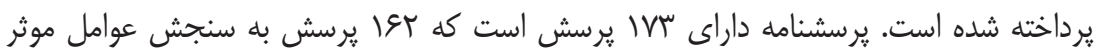

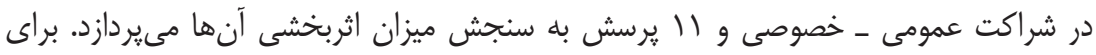

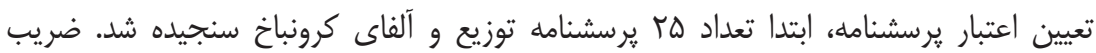

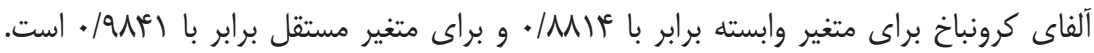

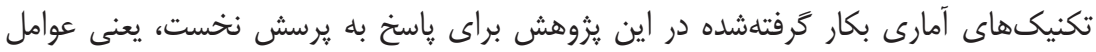

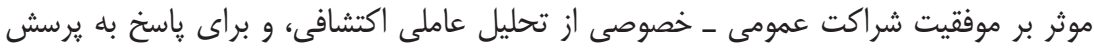

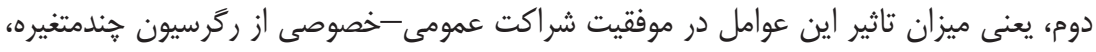

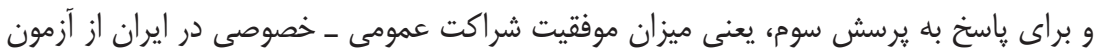
t تكمتنيره استفاده شده است.

جدول f: نمونه آمارى ثيخوهش

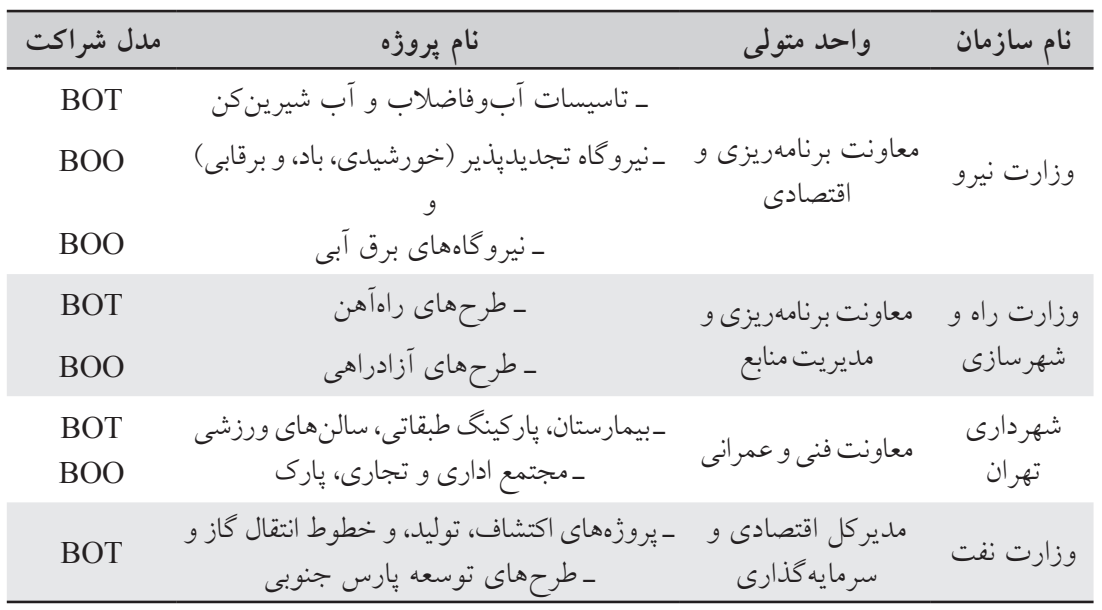

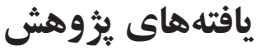

يرسش يكم: عوامل موثر بر اثربخشى شراكت عمومى ـ خصوصى كدام هستند؟ براى پاسخ به اين برسش از تكنيك تحليل عاملى اكتشافى استفاده شده است. بيش از

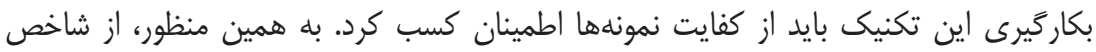
KMO 


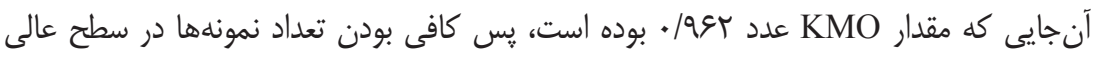

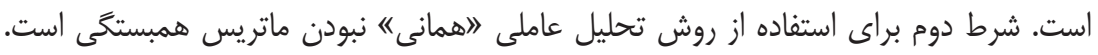

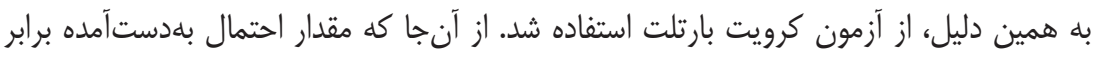

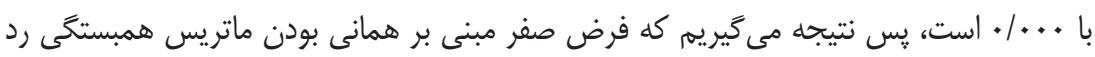

$$
\text { مىشود (ييوست (). }
$$

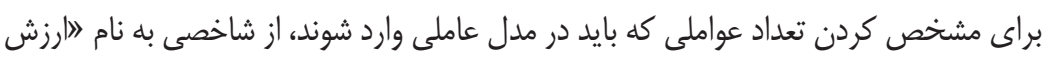

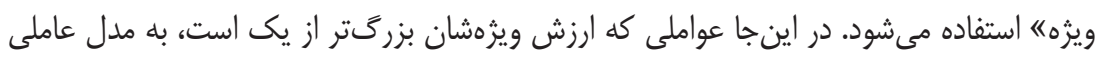

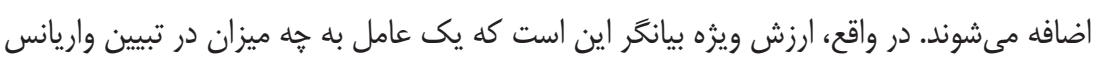

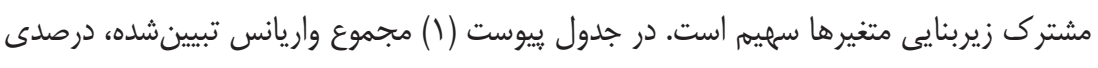

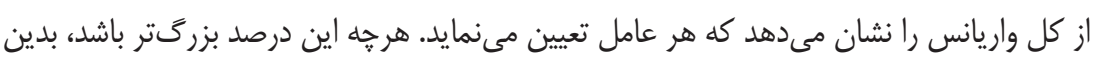

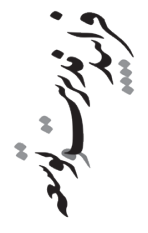

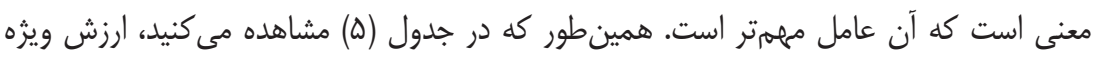

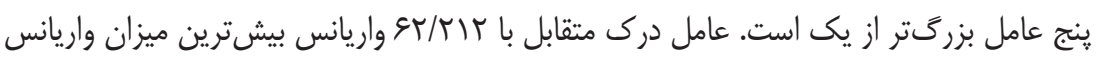

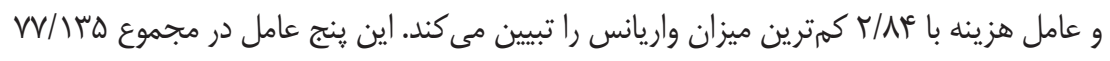
درصد واريانس متغيرها را تببين مى كنند.

جدول ه: واريانس تبيينشده، ارزش ويزٔه، و بار عاملى متغيرهاى ثروهش

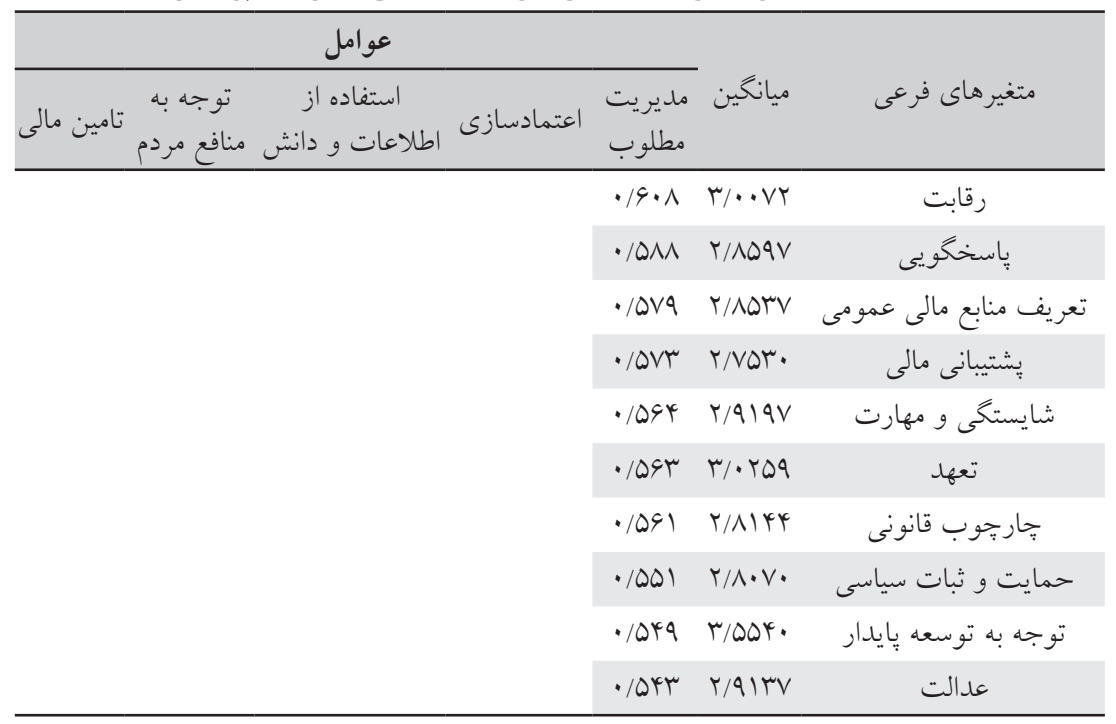


ادامه جدول ه: واريانس تبيينشده، ارزش ويزه،، و بار عاملى متغيرهاى ثئوهش

\begin{tabular}{|c|c|c|c|c|c|c|}
\hline \multicolumn{5}{|c|}{ عو امل } & \multirow[b]{2}{*}{ ميانكين } & \multirow[b]{2}{*}{ متغير هاى فرعى } \\
\hline تامين مالى & منافع مردم & اطلاعات و دانفاده از & اعتمادسازى & مل ملميريت & & \\
\hline & & & & $\cdot / \Delta r q$ & $r / 9900$ & سرعت عمل بخش عمومى \\
\hline & & & &.$- / 019$ & $r / \mu r \cdot 1$ & تحمل ريسك \\
\hline & & & & $\cdot / 014$ & r/QITV & توافق متقابل \\
\hline & & & & $\cdot / 0 \cdot r$ & $r / .1 \mu \Delta$ & تعريف مناسب مشاركت \\
\hline & & & &.$/ 494$ & r/MG & استانداردها \\
\hline & & & &.$/ 4 \& V$ & $r / \cdot v 19$ & ساماندهى مناسب \\
\hline & & & $-\cdot / \Lambda K V$ & & $r / 19 \vee \wedge$ & بيديد \\
\hline & & & $\cdot 1099$ & & $r / 9110$ & تعامل \\
\hline & & & $\cdot / \Delta 01$ & & T/qMTV & كنترل \\
\hline & & & $-\cdot / \Delta T V$ & & T/QRTY & تفوق بخش عمومى \\
\hline & & & $\cdot / \Delta M Y$ & & $T / \Lambda \cdot r t$ & برنامهريزى \\
\hline & & & $-\cdot / \Delta Q R$ & & r/Irav & اعتماد \\
\hline & & & $-\cdot / 011$ & & $r / \cdot r \mu r$ & 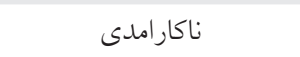 \\
\hline & & & $\cdot / 0 \cdot 0$ & & T/90H & شفافيت \\
\hline & & & $\cdot / 490$ & & $r / \backslash \wedge V \mid$ & ثبات و وضوح خطمشىها \\
\hline & & &.$/ 440$ & & $r / 1199$ & درى متقابل \\
\hline & & $\cdot 19 \vee 9$ & & & r/9994 & استفاده از مشاور \\
\hline & & $\cdot 1991$ & & & $r / 91 \cdot 1$ & نو آورى \\
\hline & & $\cdot / 94 \wedge$ & & & T/VVQQ & وجود سيستمهاى اطلاعاتى \\
\hline & $\cdot / 401$ & & & & T/VAYA & توجه به منافع اجتماع \\
\hline & $\cdot / A V T$ & & & & $r / 4119$ & آكاهى مردم \\
\hline & $\cdot|\wedge 9|$ & & & & r/AVYY & ثبت تجربهها و راهكارهاى \\
\hline .1941 & & & & & $r / Q 1 \cdot \Lambda$ & تامين مالى \\
\hline$-\cdot 19 \cdot 4^{4}$ & & & & & T/YAVA & كاهش ضايعات \\
\hline$\cdot / 0 \% 1$ & & & & & $r / r q 1)^{k}$ & ييخيرى بخش خصوصى \\
\hline $1 . / 409$ & IT/MYY & $1 \% / 99 V$ & $19 / \mathrm{Va1}$ & $r \cdot / \& \Delta Q$ & & واريانس \\
\hline I/.rt & $1 / .9 V$ & $\mid / r \& 1$ & $1 / 994$ & rT/MQG & & ارزش ويزه \\
\hline
\end{tabular}


ميزان دترمينان بهدستآمده برابر با E-231/673 است. عوامل بهدستآمده با سب هرخش و

به روش اكواماكس بلهدست آمدهاند.

يرسش دوم: عوامل شناسايیىشده تا جه اندازهبر موفقيت شر اكت عمومى ـخصوصى

تاثير دارند؟

براى ڤاسخ به يرسش دوم از ركرسيون קندمتغيره استفاده شده است. با توجه به اطلاعات

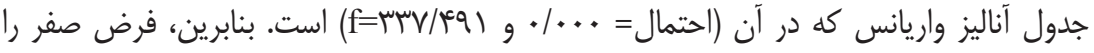

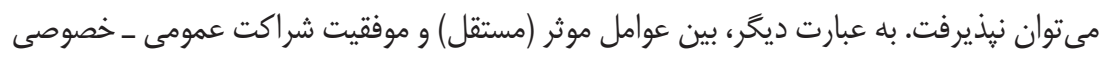

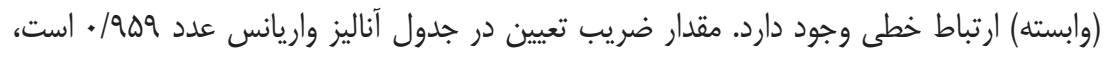
بدين معنى كه متغيرهاى مستقل 909/• تغيير را در متغير وابسته تبيين مىنمايد.

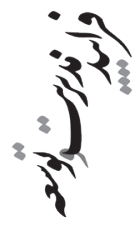

جدول و: ضرايب تاثير عوامل

\begin{tabular}{|c|c|c|c|}
\hline VIF & $\mathbf{t}$ & ضرايب استانداردشده & Model \\
\hline & TM/M & & (Constant) \\
\hline $1 / r \cdot r$ & YN/GVA & $\cdot / 009$ & مديريت مطلوب \\
\hline $1 / 111$ & $r N / \cdot 9 \Lambda$ & $\cdot / \Delta T \Lambda$ & اعتمادسازى \\
\hline $1 / .99$ & TY/TOV & $\cdot / 4 \cdot 9$ & استفاده از اطلاعات و دانش \\
\hline Defr & $19 / 4 M$ & - MOT & توجه به منافع مردم \\
\hline $1 / \cdot 9 \mathrm{~V}$ & $\mid V / r q \Lambda$ & $\cdot / 419$ & تامين مالى \\
\hline I/rTa & $-1 / 014$ & $-\cdot / \mu$ & احساس مسئوليت \\
\hline $1 / T \Lambda Y$ & $-\cdot / \wedge 9 T$ & $-\cdot / 1 \wedge$ & تغيير هاى مديريتى \\
\hline - NAY & $\cdot / T V V$ &.$/ \cdot 9$ & انعطاف يذيرى \\
\hline .1994 & . Mtrt &.$/ \cdot 9$ & يذيرش عمومى \\
\hline
\end{tabular}

با توجه به اطلاعات جدول (9)، عوامل ينج كانه: ا. مديريت مطلوب؛ ז. اعتمادسازى؛

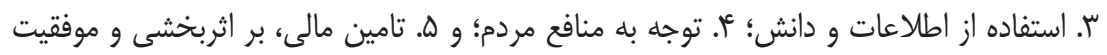

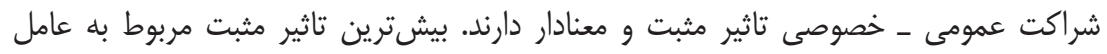

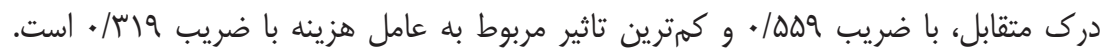


متغيرهاى احساس مسئوليت، تغييرهاى مديريتى، انعطافيذيرى، و وذيرش عمومى بر موفقيت شراكت عمومى ـ خصوصى تاثير معنادارى ندارند.

يرسش سوم: ميزان موفقيت شراكت عمومى ـ خصوصى جه اندازه است؟

جدول Y: (T متغيره)

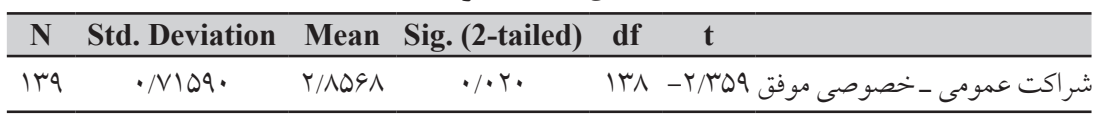

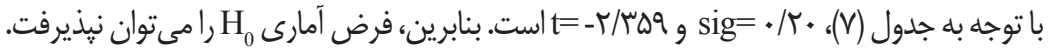

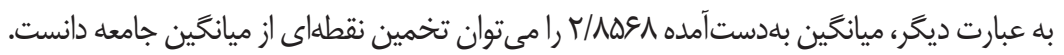

\section{بحث و نتيجه تيرى}

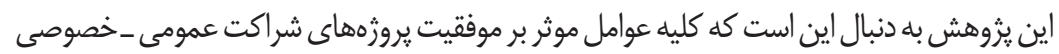

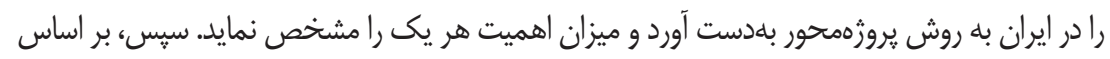

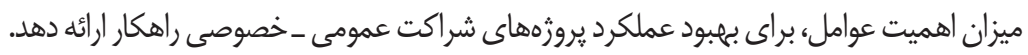

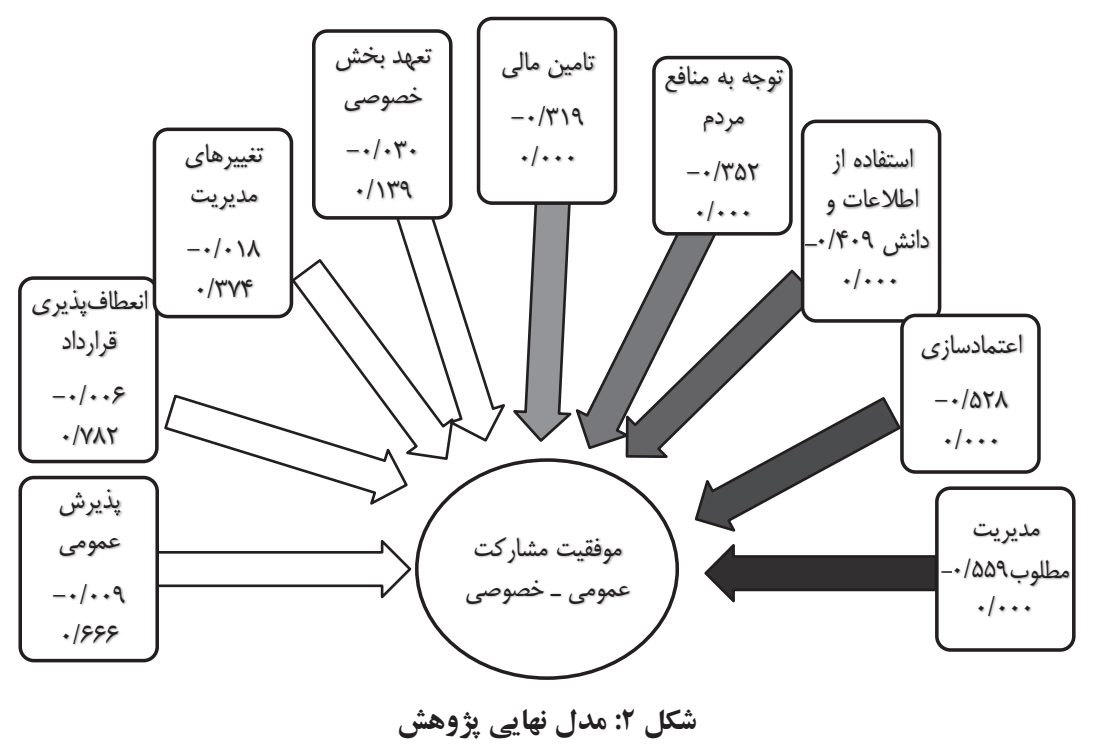


يافته هاى يزوهش بيانكر اين امر است كه اثربخشى متغير شراكت عمومى ـ خصوصى در ايران

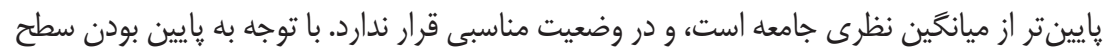

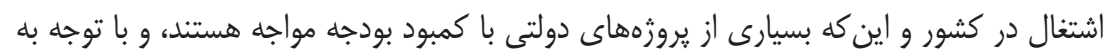

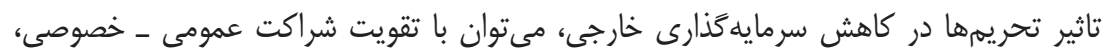

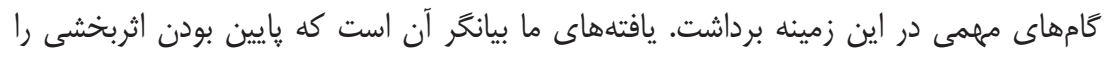

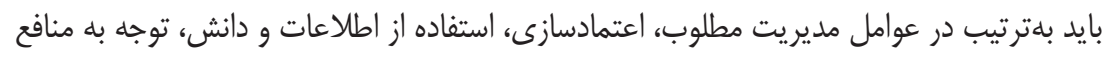

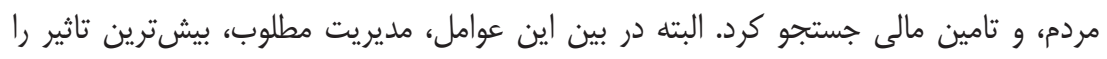

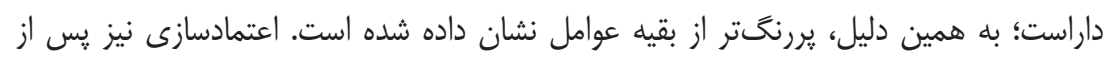

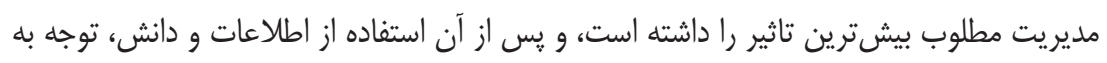

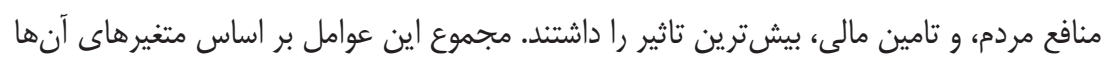
به شرح ذيل است:

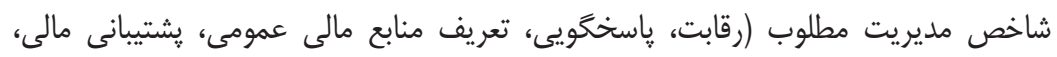

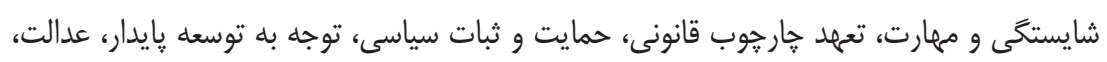

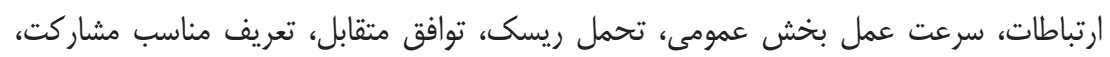

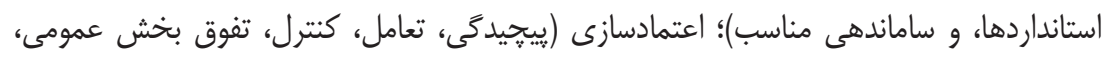

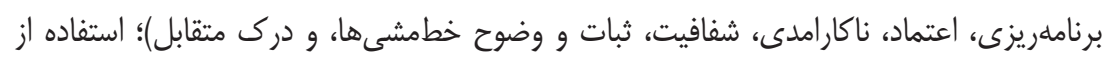

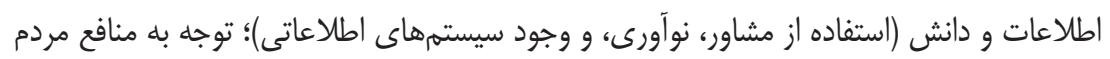

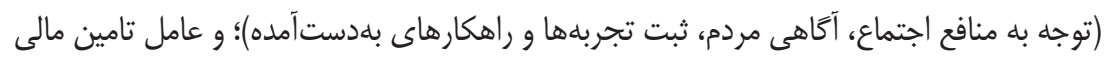

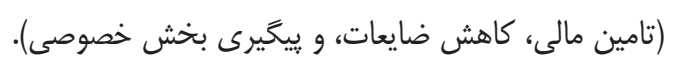

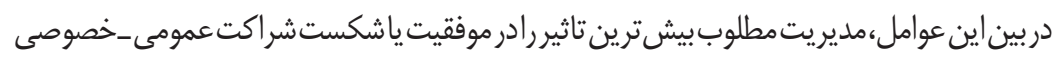
در ايران دارد كه شامل متغيرهايى جون حمايت سياسى، يشتيبانى مالى، و تعريف منابع مالى است.

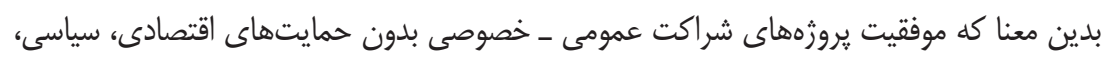

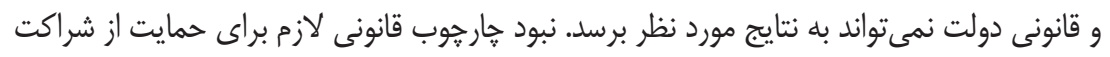

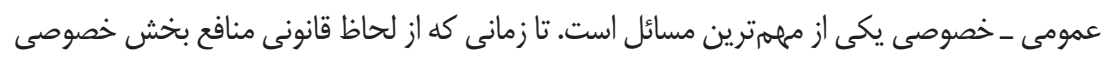

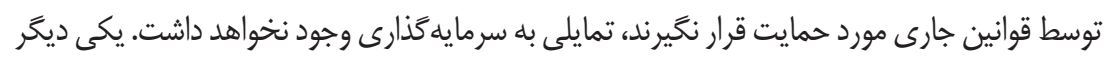

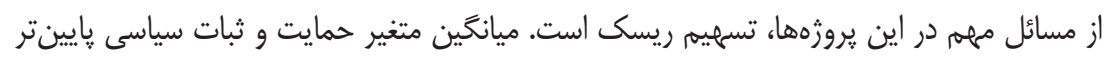

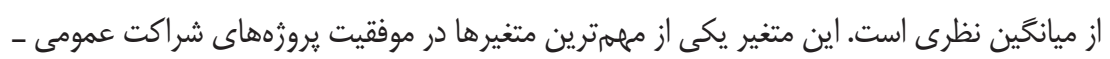
خصوصى در ايران است. حمايت دولت از بخش خصوصى شامل حمايت مالى، قانونى، و فنى است. 
ميزان سازگًارى سياستهاى اقتصادى با شراكت عمومى ـ خصوصى بدين معنا است كه در اقتصاد

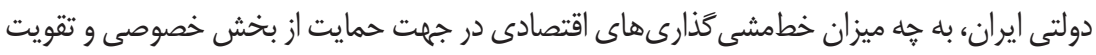

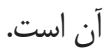

يكى ديگر از متغيرهاى مهم مديريت مطلوب، خارجوبهاى قانونى است كه ميانگين קإيينى

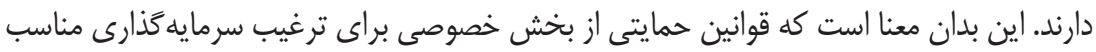
نيستند و همجنان، شكافهاى قانونى يابرجا هستند و قوانين بالادستى كاه در اجراى مفاد قرارداد

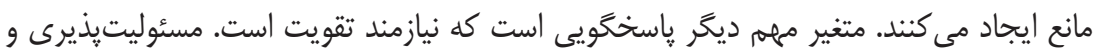

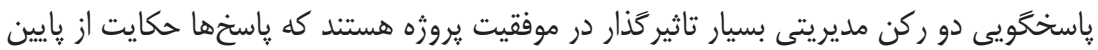

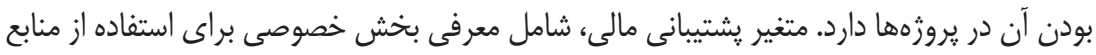

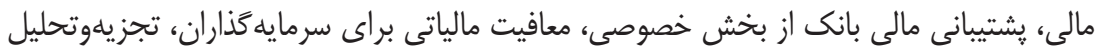
دقيق مسائل مالى، قطعيت در منابع مالى و كمكهاى دولتى، تخصيص يارانه، ميزان دسترسى

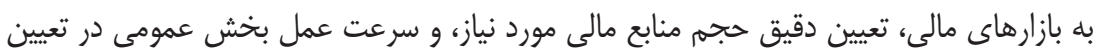

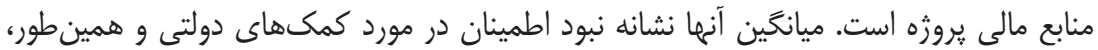

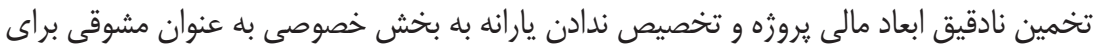

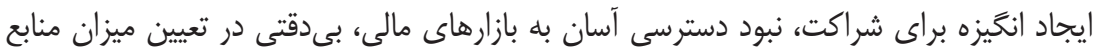

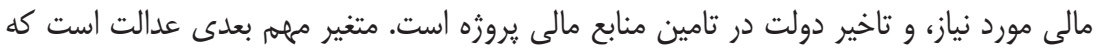

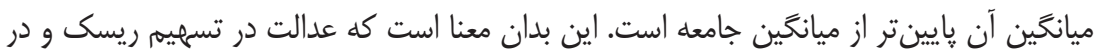

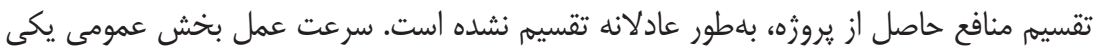

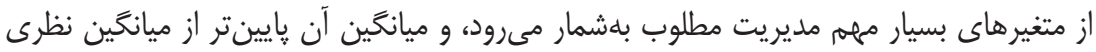
است. اين مهم نشان از كندى بخش دولتى در اجراى شراكت عمومى ـ خصوصى دارد. به همين دليل، يروزهها اغلب با تاخير به مرحله بهرهبردارى مىرسند.

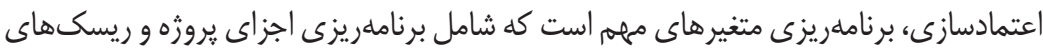

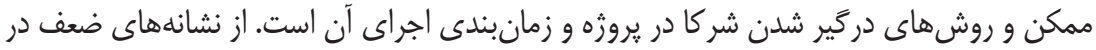

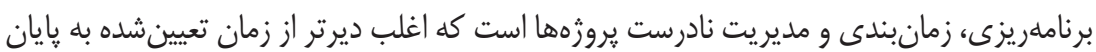
مىرسند. برنامهريزى از اركان حياتى موفقيت در هر يروزهاى است كه در اين دسته از يروزههاى

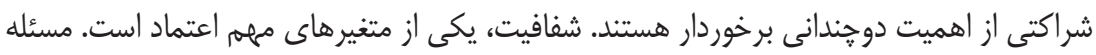
شفافيت، فرايند شفاف و روشن تصميمَّيرى است. از آنجايى كه مسئله شفافيت به معنى مشخص و روشن بودن تمام مراحل انجام كار (افتتاح دوبارة قرارداد، توافقهاى الحاقى و تكميلى، و خاتمه 
يروزه) در يروزه است، مىتواند از هرَّونه فساد در يروزه جلوكَيرى نمايد. تعامل از متغيرهاى مهمه

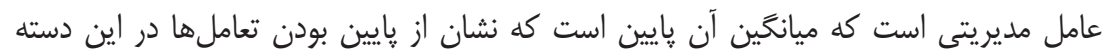

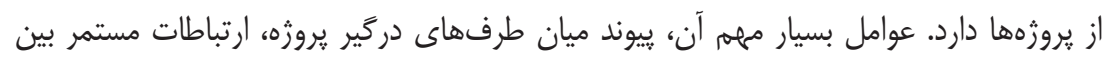

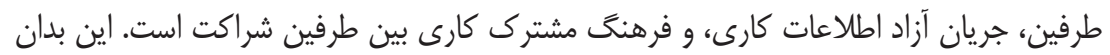

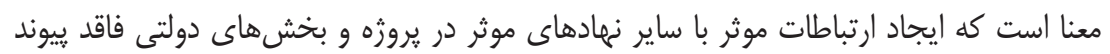

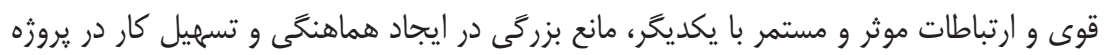

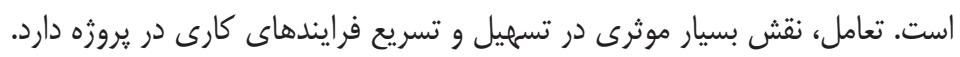

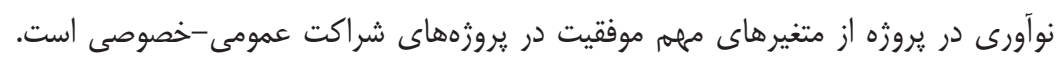

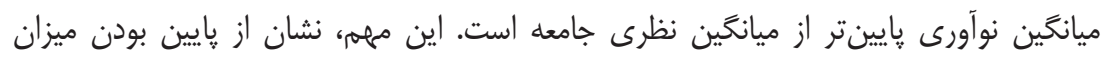

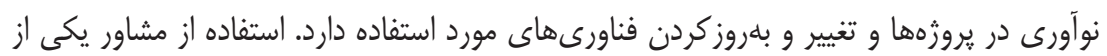

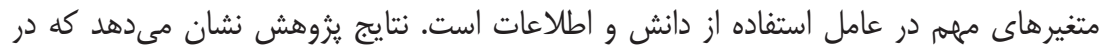
يروزههاى شراكت عمومى ـ خصوصى كمتر از مشاورهاى اجرايى و دولتى براى بيشبرد يروزه استفاده مىشود. اين موضوع مى تواند روند ييشرفت يروزه را را با اخلال مواجه نمايد.

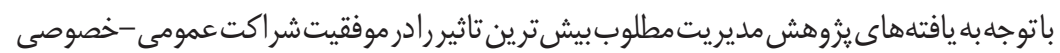
دارد. به همين دليل، بيشترين توجه به منظور موفقيت اين بروزهها بايد متمركز بر متغيرهاى مديريت مطلوب گَرد. سرعت عمل بخش عمومى، يكى از متغيرهاى بسيار مهمه مديريت مطلوب

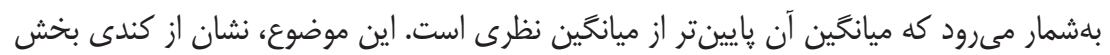

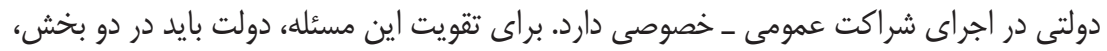

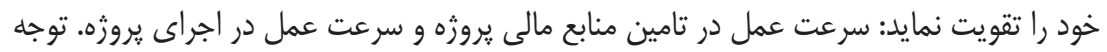

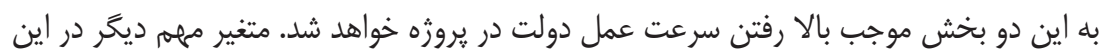

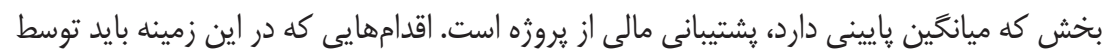
دولت انجام شوند عبارتاند از: معرفى بخش خصوصى براى استفاده از منابع مالى بانكها و تضمين بازيرداخت وامها توسط دولت، تخصيص يارانه به بخش خصوصى براى تامين مالى يروزه، برقرارى برى برائ

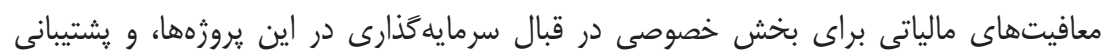

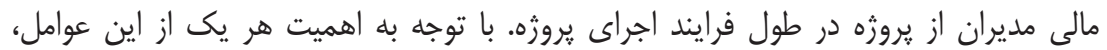

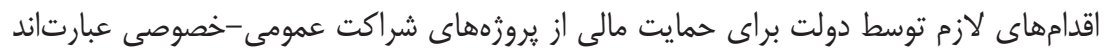

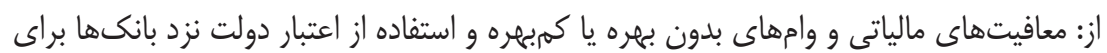

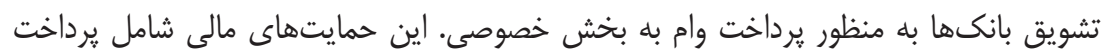




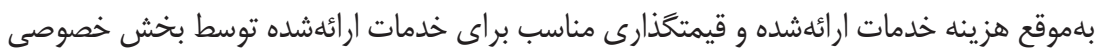

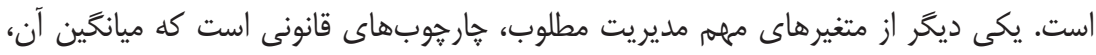
نشان از ضعف خار خوب قانونى مورد نياز براى شراكت عمومى ـ خصوصى است. اقدامهاى لازم

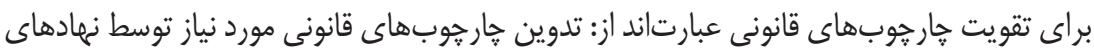

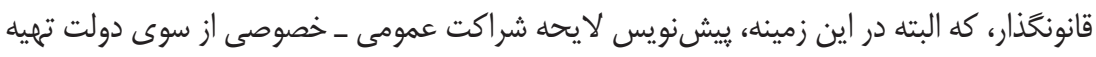
كرديده است، برطرف نمودن موانع قانونى موجود بر سر راه اجراى شراكت عمومى ـ خصوصى،

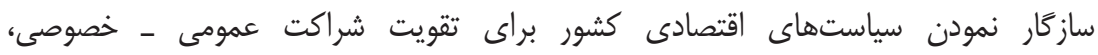

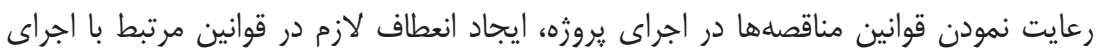

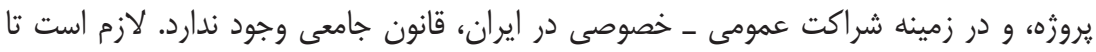

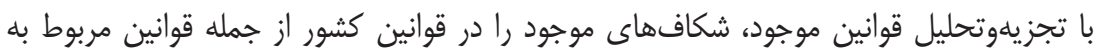
خصوصىسازى، قوانين صدور مجوز يا قوانين عمومى مانند قوانين شركتى، قانون كار، و و قوانين

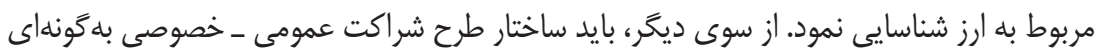

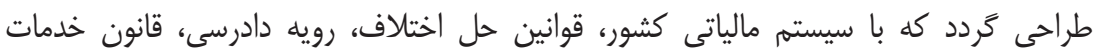

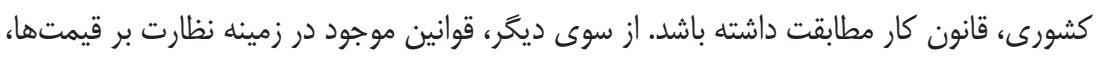

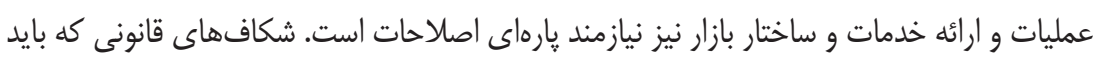

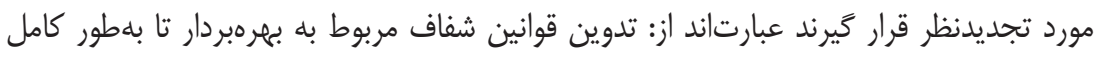

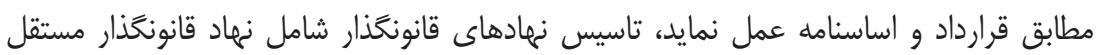

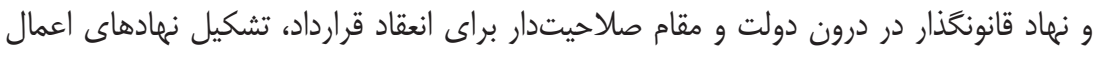

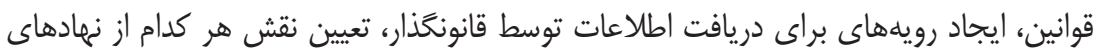

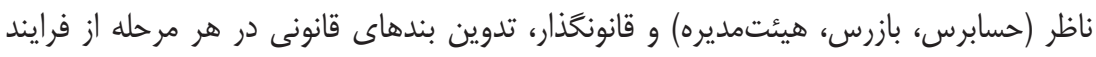

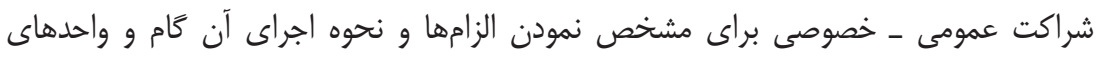
انجامدهنده آن كام.

متغير بسيار مهم ديخر حمايت و ثبات سياسى است كه نيازمند تقويت است. دولت موظف

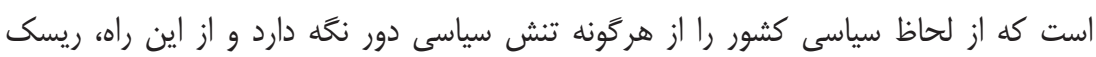

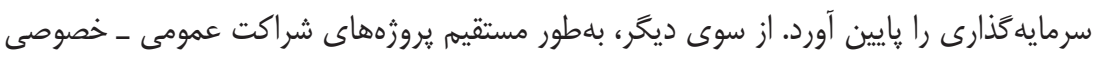

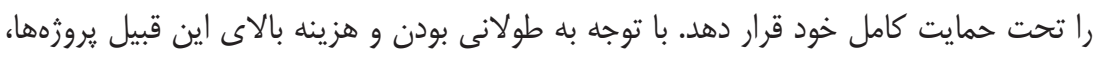
حمايتها و يشتيبانى دولت و سياستمداران بسيار ضرورى است. متغير مهم ديخر كه نيازمند تقويت

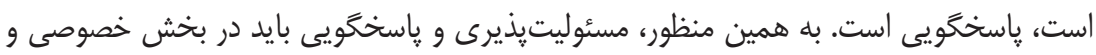


دولتى تقويت كردد. متغير مهم ديخًر در مديريت مطلوب، شايستخى و مهارت است، كه ميانگين

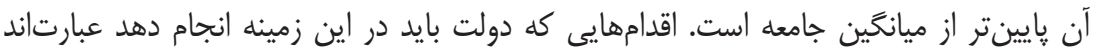

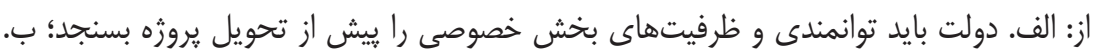

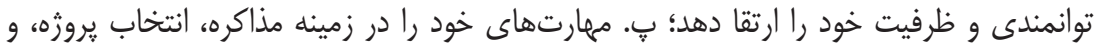
تدارك يروزه بالا ببرد؛ ت. از افراد ماهر در جاى مناسب استفاده نمايد؛ ث. مهارتها

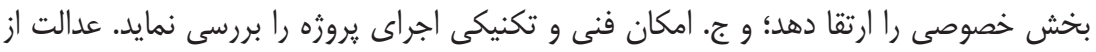

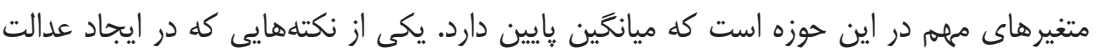

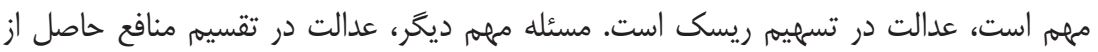

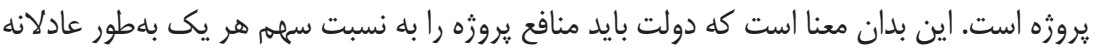

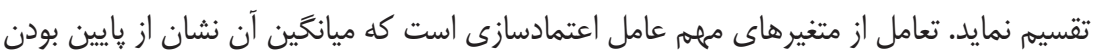
تعاملات در اين دسته از بروزهها دارد. اقدامهاى لازم براى تقويت تعامل بين دستاندركاران

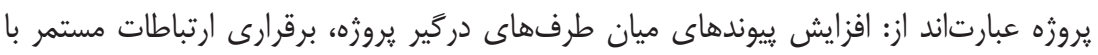
تشكيل جلسه ميان بخش خصوصى و عمومى، ايجاد فرهنگ مشترى كارى، ايجاد جريان آزاد

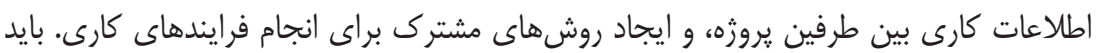

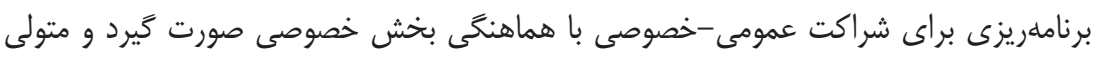
براى هماهنكى برنامهريزى شراكت بين بخش خصوصى و عمومى ايجاد شود. متغير ديخرى كه

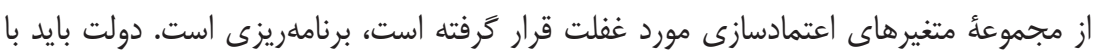
هماهنكى بخش خصوصى براى ارتقاى فرايند برنامهريزى در يروزهها، برنامه مدون و روشنى در

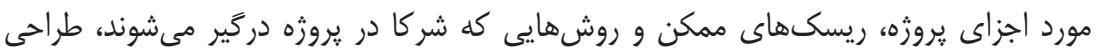
نمايد. دولت بايد برنامه زمانبندى دقيقى را به كمى كارشناسان فنى براى اجراى بهموقع و بدون تاخير يروزه طراحى نمايد. استفاده از مشاور يكى ديخر از متغيرهاى مهم استفاده از دانش و اطلاعات است كه مورد

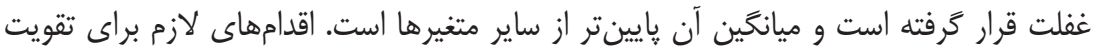

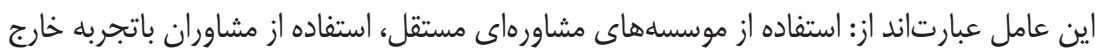

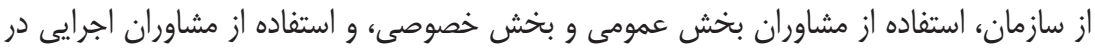

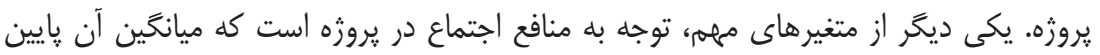

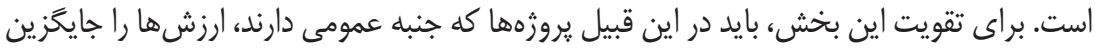

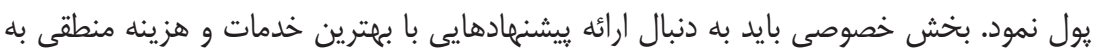


نفع مصرفكننده نهايى باشد. متغير مهم بعدى شفافيت است كه ميانكين آن بايينتر از ميانكين نظرى است. شفافيت يكى از متغيرهاى مهرم در زمينُٔ اعتمادسازى است. دولت بايد براى بالا

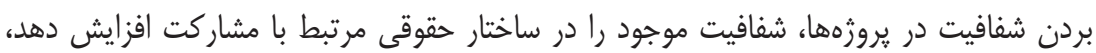

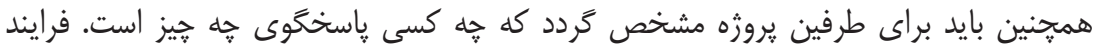

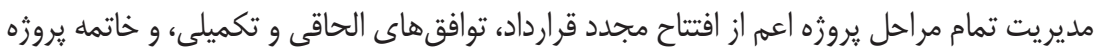

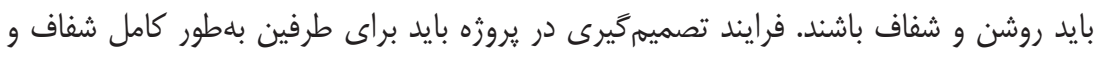

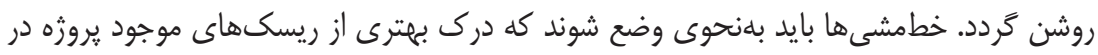

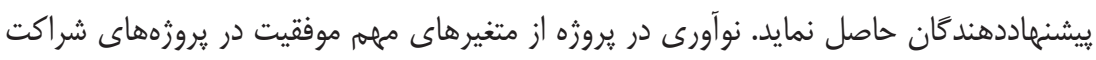
عمومى-خصوصى است كه بايد با انتقال فناورىهاى نو، انجام مراحل بروزهه را تسهيل نمايد.

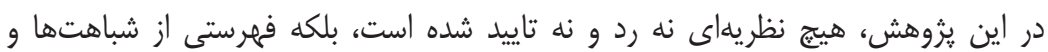
تفاوتهاى كليه عوامل موثر بر موفقيت شراكت عمومى ـ خصوصى مطرحشده در نظريههاى

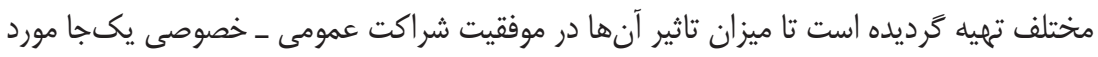

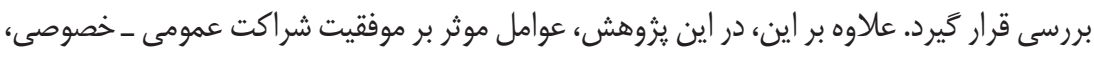
در خود يروزهها مورد سنجش قرار كَرفتهاند.

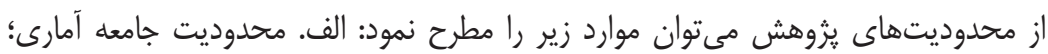
بدين معنا كه اين ثروهش در وزارتخانهاى نيرو، راه و شهرسازى، نفت، و شهردارى تهران

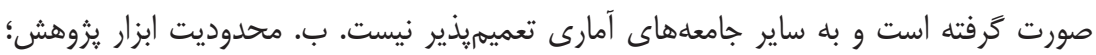

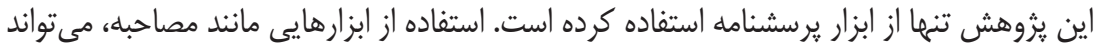

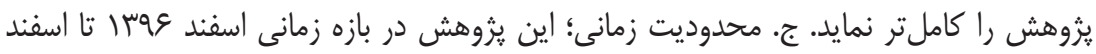
Vوسا صورت كرفته است و به زمانهاى ديخر تعميميذير نيست.

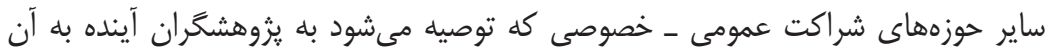

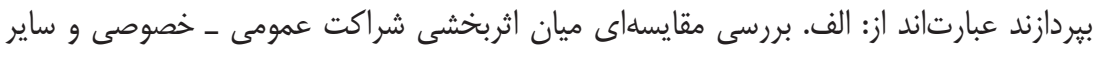
روشهاى واكذارى خدمات عمومى؛ ب. بررسى اثربخشى شراكت عمومى ـ خصوصى از ديدكاه

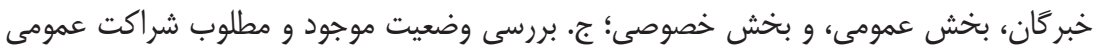

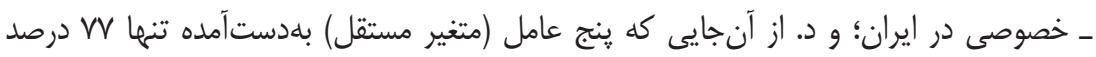

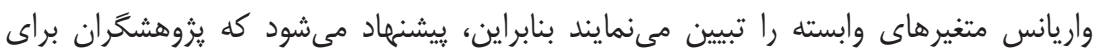
شناسايى ساير عوامل در يثوهش وائهاى آينده تمركز كنند. 


\section{منابع}
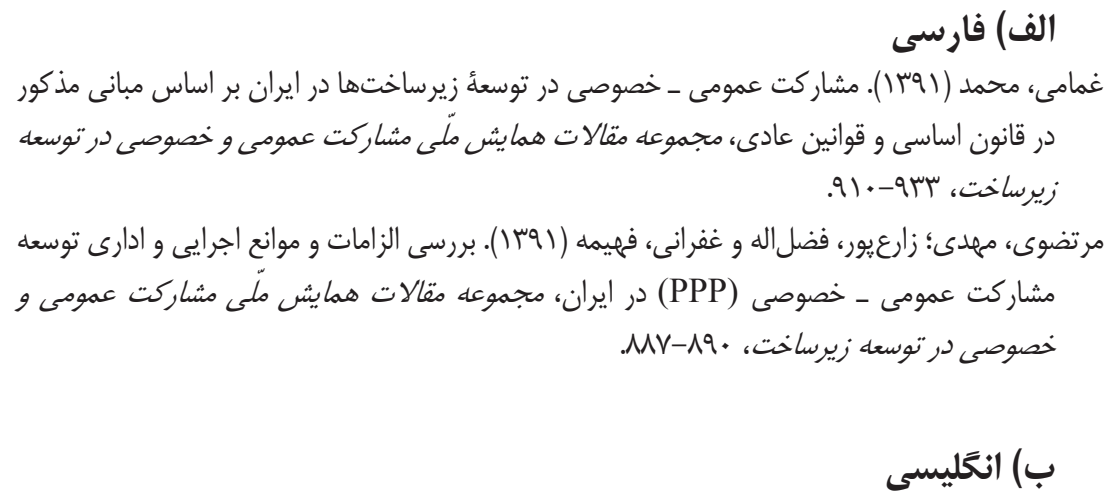

Akintoye, A., Hardcastle, C., Beck, M., Chinyio, E., \& Asenova, D. (2003). Achieving Best Value in Private Finance Initiative Project Procurement. Construction Management and Economics, 21(5), 461-470.

Abdul-Rashid, A., Puteri, S., Ahmed, U., \& Mastura, J. (2006). Public Private Partnerships (PPP) in Housing Development: the Experience of IJM Malaysia in Hyderabad, India. Accelerating Excellence in the Built Environment, 2-4.

Alinaitwe, H., \& Ayesiga, R. (2013). Success Factors for the Implementation of Public-Private Partnerships in the Construction Industry in Uganda. Journal of Construction in Developing Countries, 18 (2), 1-14.

Agrawal, R. (2010). Successful Delivery of Public-Private Partnerships for Infrastructure Development. Jaypee Institute of Information Technology, Noida, India.

Aziz, A. R. A. (2010). Housing Private Public Partnerships: Perspectives from the Governement Agencies. Paper Presented at the 4th NAPREC Conference, (September 2010).

Bloomfield, P. (2006). The Challenging Business of Long-Term PublicPrivate Partnerships: Reflections on Local Experience. Public Administration Review, 66 (3), 400-411.

Chan, A. P., Lam, P. T., Chan, D. W., Cheung, E., \& Ke, Y. (2009). Drivers for Adopting Public Private Partnerships-Empirical Comparison between China and Hong Kong Special Administrative Region. Journal of Construction Engineering and Management, 135 (11), 1115-1124.

Chan, A. P., Lam, P. T., Chan, D. W., \& Cheung, E. (2008). Application of Public Private Partnership (PPP) in Hong Kong Special Administrative Region-the Critics' Perspectives. 
Corbett, P., \& Smith, R. (2006). An Analysis of the Success of the Private Finance Initiative as the Government's Preferred Procurement Route. Paper Presented at the Proceedings of the Accelerating Excellence in the Built Environment Conference.

Cheung, E., Chan, A. P., \& Kajewski, S. (2009). Enhancing Value for Money in Public Private Partnership Projects: Findings from a Survey Conducted in Hong Kong and Australia Compared to Findings from Previous Research in the UK. Journal of Financial Management of Property and Construction, 14(1), 7-20.

Dulaimi, M. F., Alhashemi, M., Ling, F. Y. Y., \& Kumaraswamy, M. (2010). The Execution of Public-Private Partnership Projects in the UAE. Construction Management and Economics, 28(4), 393-402.

El-Gohary, N. M., Osman, H., \& El-Diraby, T. E. (2006). Stakeholder Management for Public Private Partnerships. International Journal of Project Management, 24(7), 595-604.

Jamali, D. (2004). Success and Failure Mechanisms of Public Private Partnerships (PPPs) in Developing Countries: Insights from the Lebanese Context. International Journal of Public Sector Management, 17(5), 414-430.

Grimsey, D., \& Lewis, M. (2007). Public Private Partnerships and Public Procurement. Agenda: A Journal of Policy Analysis and Reform, 14(2), 171-188.

Jacobson, C., \& Ok Choi, S. (2008). Success Factors: Public Works and Public-Private Partnerships. International Journal of Public Sector Management, 21(6), 637-657.

Haarhoff, K. J. (2009). Public Private Partnerships as an Alternative Service Delivery Option: A Multiple Case Study of the Healthcare Sector. Stellenbosch: University of Stellenbosch.

Hardcastle, C., Edwards, P., Akintoye, A., \& Li, B. (2005). Critical Success Factors for PPP/PFI Projects in the UK Construction Industry: A Factor Analysis Approach. Construction Management and Economics, 23(5), 459-471. Helmy, M. A. (2011). Investigating the Critical Success Factors for PPP Projects in Kuwait. (Master of Science Thesis), KTH Royal Institute of Technology.

Ismail, S. (2013). Critical Success Factors of Public Private Partnership (PPP) Implementation in Malaysia. Asia-Pacific Journal of Business Administration, 5(1), 6-19.

Jefferies, M. (2006). Critical Success Factors of Public Private Sector Partnerships:

A Case Study of the Sydney SuperDome. Engineering, Construction and Architectural Management, 13(5), 451-462. 
Ke, Y., Wang, S., Chan, A. P., \& Lam, P. T. (2010). Preferred Risk Allocation in China's Public-Private Partnership (PPP) Projects. International Journal of Project Management, 28(5), 482-492.

Kanter, R. M. (1999). From Spare Change to Real Change: The Social Sector as Beta Site for Business Innovation. Harvard Business Review, 77(3), 122-123.

Kettler, H., \& Towse, A. (2002). Public Private Partnerships for Research and Development: Medicines and Vaccines for Diseases of Poverty. Monographs.

Kwak, Y. H., Chih, Y., \& Ibbs, C. W. (2009). Towards a Comprehensive Understanding of Public Private Partnerships for Infrastructure Development. California Management Review, 51(2), 51-78.

Khanom, N. A. (2010). Conceptual Issues in Defining Public Private Partnerships (PPPs). International Review of Business Research Papers, $6(2), 150-163$.

Tang, L. (2011). Effective and Efficient Briefing in Public Private Partnership Projects in the Construction Industry. The Hong Kong Polytechnic University.

Li, B., Akintoye, A., Edwards, P. J., \& Hardcastle, C. (2005). Critical Success Factors for PPP/PFI Projects in the UK Construction Industry. Construction Management and Economics, 23(5), 459-471.

Liu, T., \& Wilkinson, S. (2011). Adopting Innovative Procurement Techniques: Obstacles and Drivers for Adopting Public Private Partnerships in New Zealand. Construction Innovation, 11(4), 452-469.

Kalampukatt, P. K., \& Mittal, A. K. (2010). Partnership Challenges in Achieving Common Goals: A Study of Public Private Partnership in E-Governance Projects. (Master Program in Strategic Project Management (European)), Umeå School of Business.

McQuaid, R. W. (2000). The Theory of Partnership: Why have Partnerships? Public-Private Partnerships (pp. 27-53): Routledge.

Qiao, L., Wang, S. Q., Tiong, R. L., \& Chan, T.-S. (2001). Framework for Critical Success Factors of BOT Projects in China. Journal of Project Finance, 7(1), 53-61.

Rondinelli, D. (2004). Partnering for Development: Government-Private Sector: Online][Accessed 27 December 2015].

Sudarto, S., Trigunarsyah, B., \& Abidin, I. (2007). Lesson Learned Corrective Action in Internal Factors of Construction Company in Indonesia. Paper Presented at the Fourth International Conference on Construction in the 21st Century - Accelerating ... Engineering, Management and Technology, Australia 
Stonehouse, J. H., Hudson, A. R., \& O'Keefe, M. J. (1996). PrivatePublic Partnerships: The Toronto Hospital Experience. Canadian Business Review, 23(1), 17-20.

Trafford, S., \& Proctor, T. (2006). Successful Joint Venture Partnerships: Public-Private Partnerships. International Journal of Public Sector Management, 19(2), 117-129.

Tiong, R. L. (1996). CSFs in Competitive Tendering and Negotiation Model for BOT Projects. Journal of Construction Engineering and Management, 122(3), 205-211.

Wah, W. M. (2006). Satisfying All Stakeholders in Evaluating the Feasibility of Public-Private Partnership Projects: A Structural Equation Model Approach. (A Thesis Submitted in Partial Fulfillment of the Requirements for the Degree of Master of Philosophy), University of Hong Kong.

Zhang, X. (2005). Critical Success Factors for Public-Private Partnerships in Infrastructure Development. Journal of Construction Engineering and Management, 131(1), 3-14.

Zhao, Z.-Y., Zuo, J., \& Zillante, G. (2013). Factors Influencing the Success of BOT Power Plant Projects in China: A Review. Renewable and Sustainable Energy Reviews, 22(1), 446-453.

Yang, T., Long, R., Cui, X., Zhu, D., \& Chen, H. (2017). Application of the public-Private Partnership Model to Urban Sewage Treatment. Journal of Cleaner Production, 142(1), 1065-1074. 

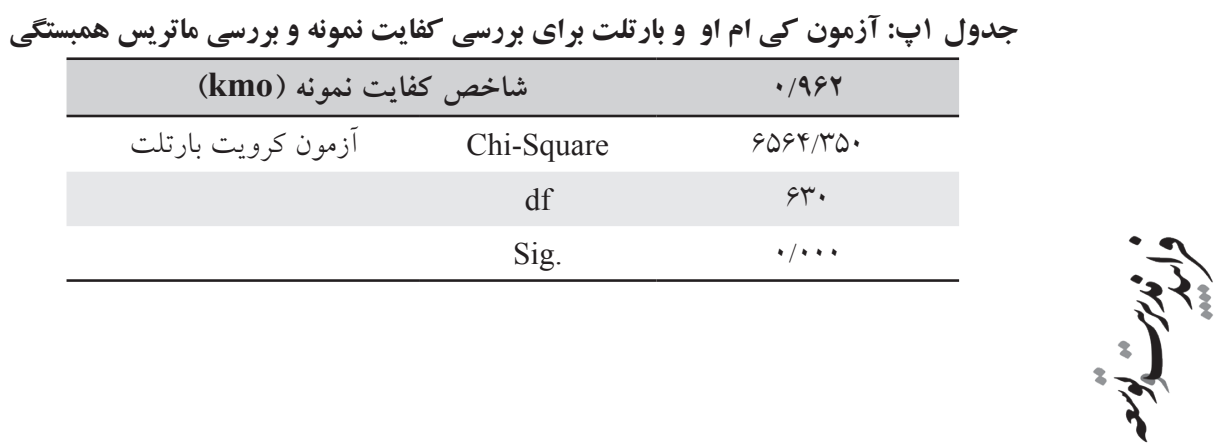

7
2
0
2
1
3
3
5
1
3
3
0
1
3
7
7
-

